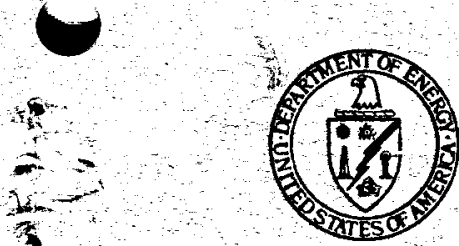

\title{
Utah Geothermal Institutional Handbook
}

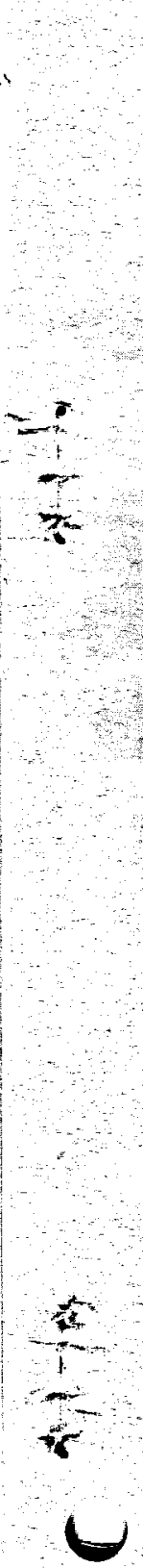

A User's Guide of Agencies Regulations, Permits and Aids for Geothermal Development 1982
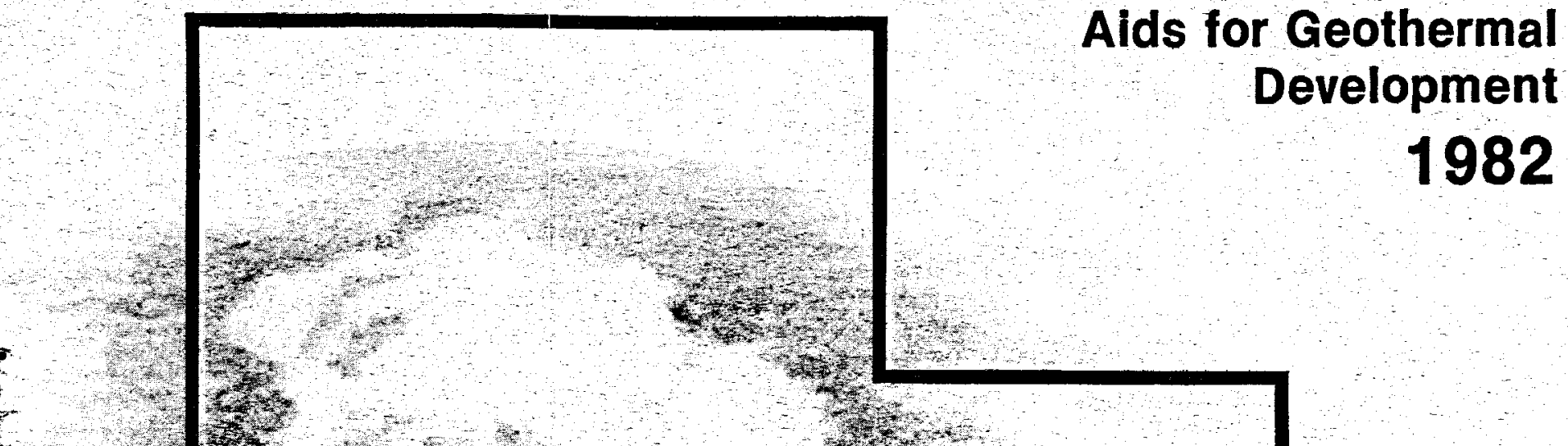

$+2+2+2$

$+2^{2}$

$+2$

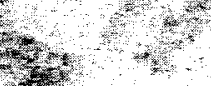

6.t.
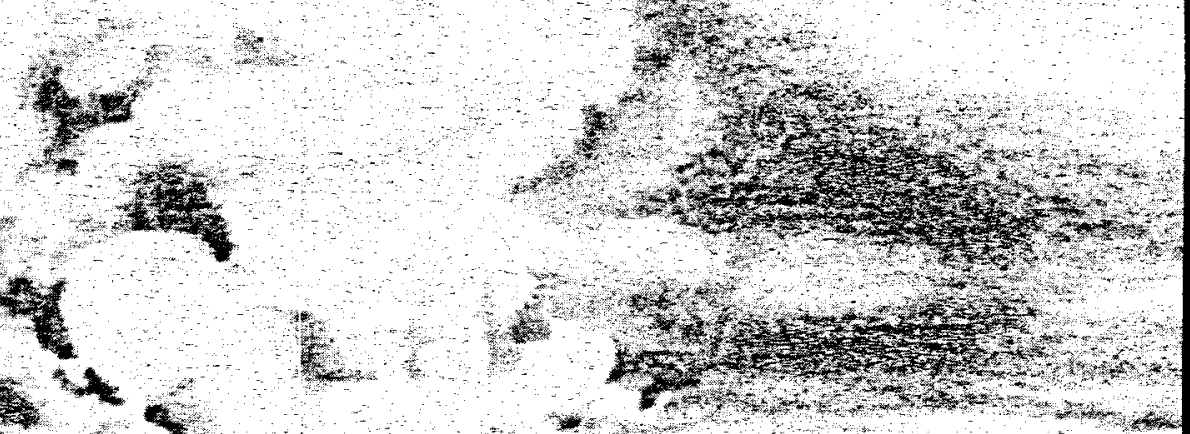

aㄴ.
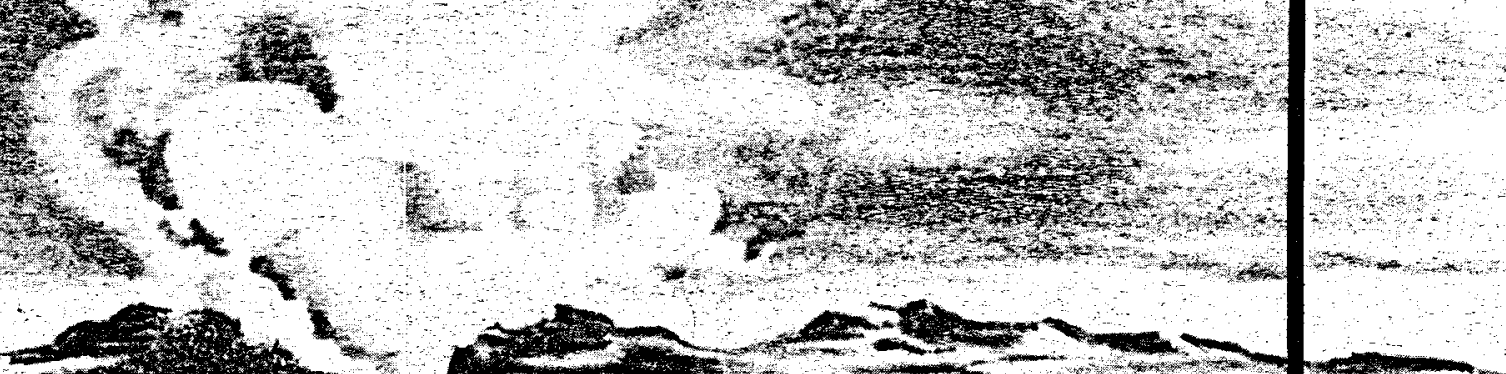

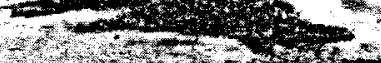
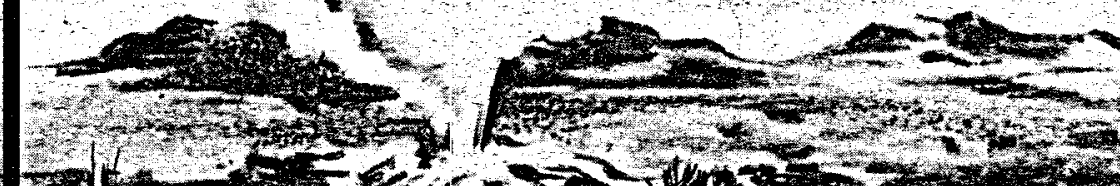

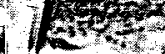

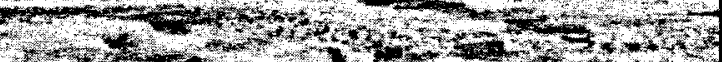
$-1+\sin 2$
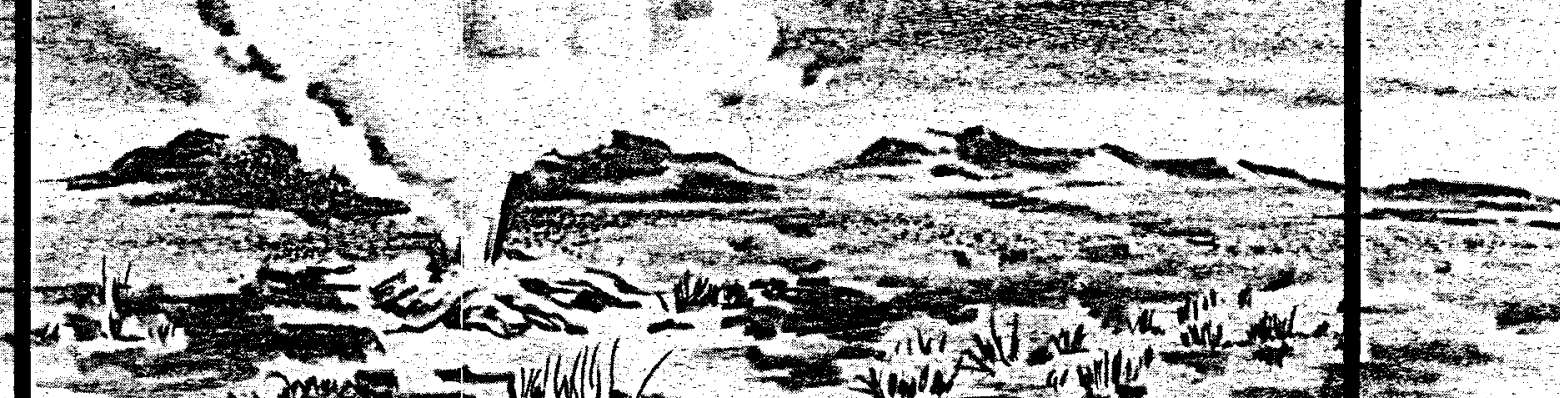

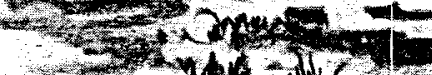

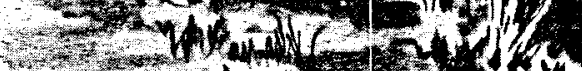

thi:

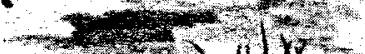

$$
x+x+3+2 y
$$

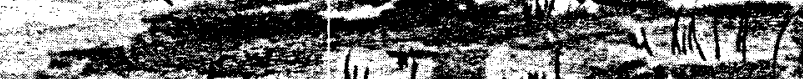

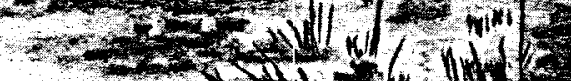

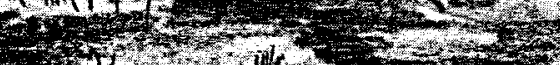

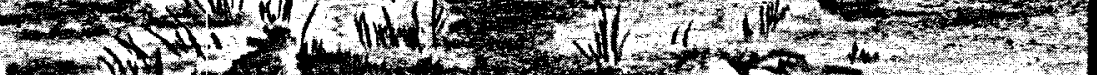

(5)

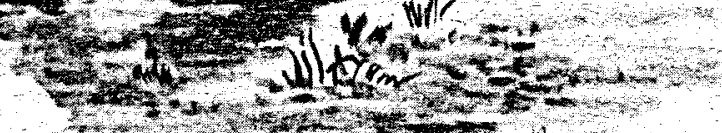

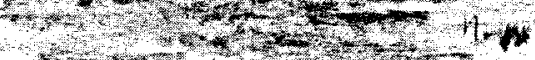

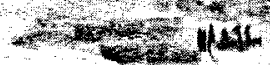

$-m-\infty$
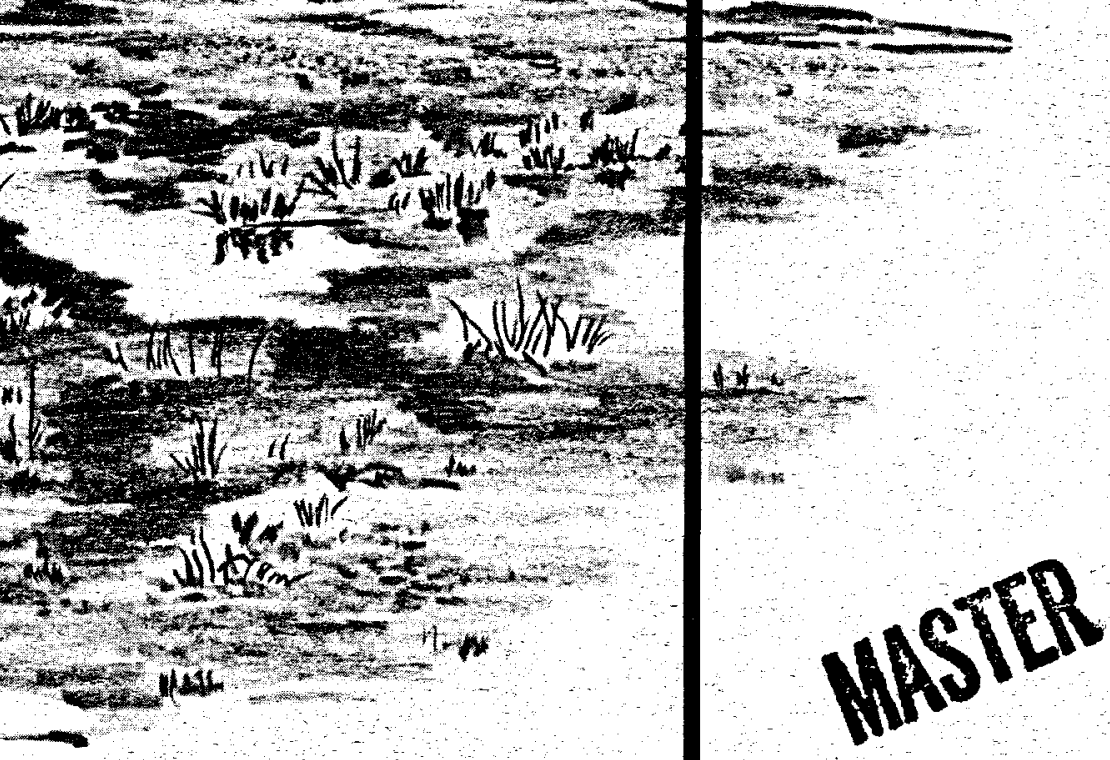


\section{DISCLAIMER}

This report was prepared as an account of work sponsored by an agency of the United States Government. Neither the United States Government nor any agency Thereof, nor any of their employees, makes any warranty, express or implied, or assumes any legal liability or responsibility for the accuracy, completeness, or usefulness of any information, apparatus, product, or process disclosed, or represents that its use would not infringe privately owned rights. Reference herein to any specific commercial product, process, or service by trade name, trademark, manufacturer, or otherwise does not necessarily constitute or imply its endorsement, recommendation, or favoring by the United States Government or any agency thereof. The views and opinions of authors expressed herein do not necessarily state or reflect those of the United States Government or any agency thereof. 


\section{DISCLAIMER}

Portions of this document may be illegible in electronic image products. Images are produced from the best available original document. 
Printed in the United States of Americe

Available from

National Technical Information Service

U.S. Department of Commerce

5285 Port Royal Road

Springfield, VA 22161

NTIS Price Codes: Printed Copy A05

Microfiche A01

\section{DISCLAIMER}

This book was prepared as an account of work sponsored by an agency of the United States Government. Neither the United States Government nor any agency thereof, nor any of their employees, makes any warranty, express or implied, or assumes any legal liability or responsibility for the accuracy, completeness, or usefulness of any information, apparatus, product or process disclosed, or represents that its use would not infringe privately owned rights. References herein to any specific commercial product, process, or service by trade name, trademark, manufacturer, or otherwise, does not necessarily constitute or imply its endorsement, recommendation, or favoring by the United States Government or any agency thereof. The views and opinions of authors expressed herein do not necessarily state or reflect those of the United States Government or any agency thereof. 
DOE/ID/12016--2

DE82 017592

UTAH GEOTHERMAL INSTITUTIONAL HANDBOOK

Prepared by

L. Ward Wagstaff

Stanley Green

\section{Utah Geothermal Commercialization Program Utah Division of Water Rights 1636 West North Temple Salt Lake City, Utah 84116}

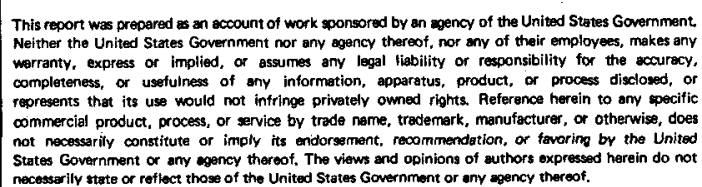

Prepared for

U.S. Department of Energy

Division of Geothermal Energy

Under Contract No. DE-FC07-79ID12016 
TABLE OF CONTENTS

I INTRODUCTION $\ldots \ldots \ldots \ldots \ldots \ldots \ldots \ldots \ldots \ldots \ldots \ldots \ldots \ldots \ldots \ldots \ldots, \ldots \ldots \ldots$

II PRINCIPAL AGENCIES AND PERSONNEL $\ldots \ldots \ldots \ldots \ldots \ldots \ldots \ldots \ldots \ldots \ldots$

Table 1 - Principal Agencies and Personnel................. 3

III APPLICABLE STATE LEGISLATION $\ldots \ldots \ldots \ldots \ldots \ldots \ldots \ldots \ldots \ldots \ldots$

Definition and Administration.........................6 6

Leasing......................................... 7

Exploration and Development: Water Rights............... 8

Geothermal Resources at High Temperatures............. 8

Low and Moderate Temperatures: Utah Water Law........... 10

Environmental Regulations ........................... 11

Water Quality $\ldots \ldots \ldots \ldots \ldots \ldots \ldots \ldots \ldots \ldots \ldots \ldots \ldots \ldots, \ldots \ldots$

Air Quality $\ldots \ldots \ldots \ldots \ldots \ldots \ldots \ldots \ldots \ldots \ldots \ldots \ldots \ldots \ldots \ldots$

State Taxes......................................... 12

Tax Incentives $\ldots \ldots \ldots \ldots \ldots \ldots \ldots \ldots \ldots \ldots \ldots \ldots \ldots, 12$

District Heating and Special Uses ...................... 12

Public Utilities ...................................13

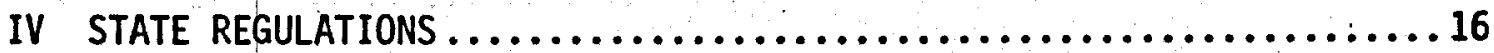

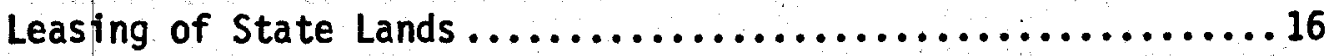

Exploration and Development......................... 18

Exploration Drilling............................ 18

Test Well Permits...............................19

Production Drilling ........................21 


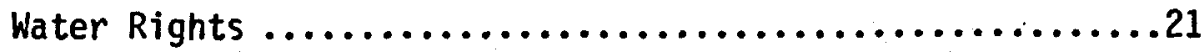

Consumptive and Non-consumptive Water Rights .......22

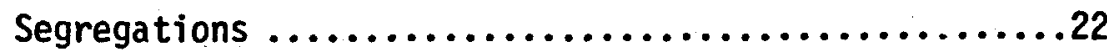

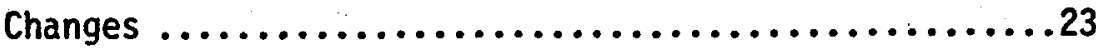

Drilling Requirements $\ldots \ldots \ldots \ldots \ldots \ldots \ldots \ldots \ldots \ldots \ldots$

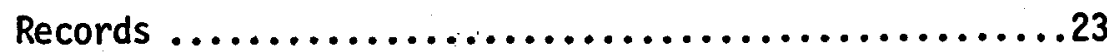

Injection Wells $\ldots \ldots \ldots \ldots \ldots \ldots \ldots \ldots \ldots \ldots \ldots . \ldots . \ldots . \ldots$

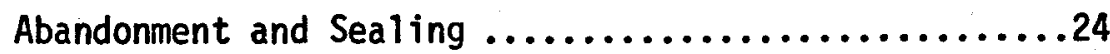

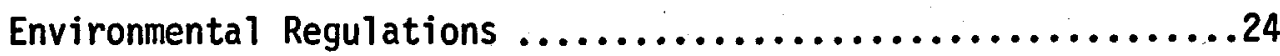

Water Pollution Control ...........................25

Surface Discharge $\ldots \ldots \ldots \ldots \ldots \ldots \ldots \ldots \ldots \ldots \ldots \ldots \ldots$

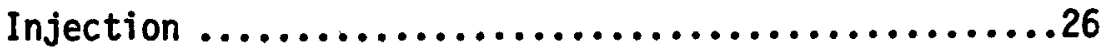

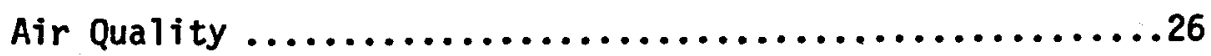

Other Agencies and Permits $\ldots \ldots \ldots \ldots \ldots \ldots \ldots \ldots \ldots \ldots \ldots$

Public Utility Regulations .......................28

Local Permits and Regulations $\ldots \ldots \ldots \ldots \ldots \ldots \ldots \ldots . \ldots . \ldots . \ldots . \ldots$

$v$ STATE INFORMATION AND ASSISTANCE $\ldots \ldots \ldots \ldots \ldots \ldots \ldots \ldots \ldots \ldots \ldots \ldots \ldots \ldots \ldots . \ldots \ldots$

Utah Energy office $\ldots \ldots \ldots \ldots \ldots \ldots \ldots \ldots \ldots \ldots \ldots \ldots \ldots \ldots$

Utah Geological and Mineral Survey ....................29

Geothermal Commercialization Program ......................

Industrial Promotion Division $\ldots \ldots \ldots \ldots \ldots \ldots \ldots \ldots \ldots \ldots$

Multi-county Economic Development Agencies ..................

VI FEDERAL REgULATIONS AND PERMITTING PROCEDURES $\ldots \ldots \ldots \ldots \ldots \ldots \ldots . \ldots 32$

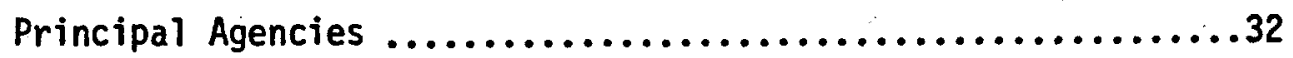

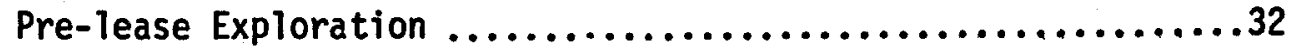

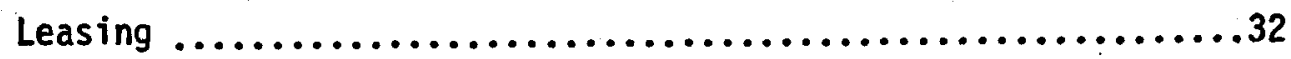

Non-competitive Leases $\ldots \ldots \ldots \ldots \ldots \ldots \ldots \ldots \ldots \ldots \ldots$

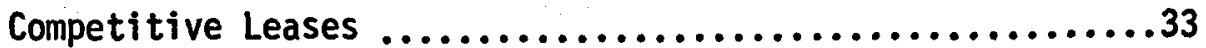


Post-Lease Exploration ...........................34

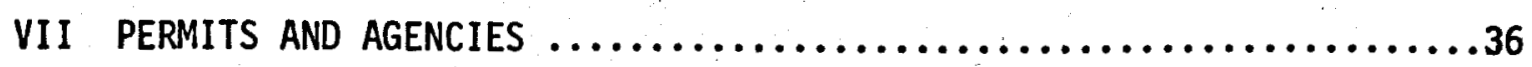

Table 2 - Permits and Agencies ..........................

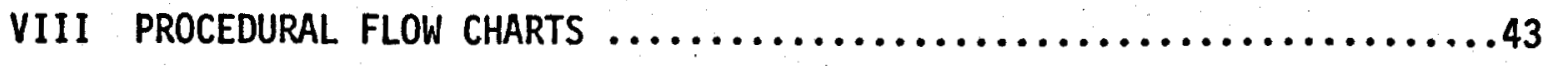

State Leases - Noncompetitive .....................44

State Leases - Simultaneous Filing ...................45

State Environmental Health Permits - Bureau of Water

Pollution Control ............................46

Detailed Procedure for the Granting of Water Rights .........49

Typical Procedure for Major Development on BLM

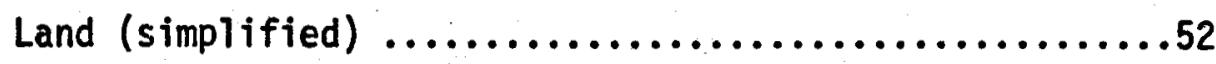

Typical Resource Assessment Program - Low or Moderate

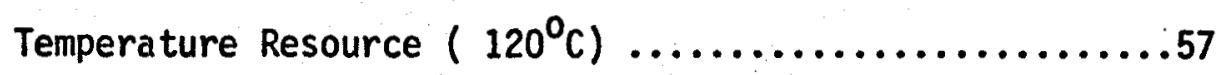

Typical Procedure for Development of Low or Moderate

Temperature Resources $\left(120^{\circ} \mathrm{C}\right) \ldots \ldots \ldots \ldots \ldots \ldots \ldots \ldots \ldots \ldots . \ldots \ldots$

IX HEAT PUMP APPLICATIONS OF GROUNDWATER USE $\ldots \ldots \ldots \ldots \ldots \ldots \ldots \ldots 65$

$X$ TECHNICAL BIBLIOGRAPHY ...........................67

XI APPENDIX A - UTAH GEOTHERMAL RESOURCES CONSERVATION ACT $\ldots \ldots \ldots \ldots 71$ 


\section{Introduction}

The purpose of this handbook is to assist interested persons in understanding and complying with the various laws, regulations, and procedures associated with the development of geothermal resources in Utah. Included in the Handbook are lists of the main permits required and the names of agencies and persons associated with the permits; a summary of pertinent laws, regulations, and permits; and charts outlining typical development and permitting procedures. The Handbook is intended only as a general guide; the best and most reliable guidance for a prospective developer is through direct interaction with the respective regulatory agencies. 


\section{PRINCIPAL AGENCIES AND PERSONNEL}

The following section contains a listing of principal agencies with which a prospective geothermal developer might come in contact in the course of a project. Included are the addresses and phone numbers of the agencies and the name of the director. In addition, the name and phone number of a suggested contact person for each agency is listed below the address of the agency. 
TABLE 1. PRINCIPAL AGENCIES AND PERSONNEL

State Agencies

Utah Department of Natural Resources and Energy

Temple A. Reynolds, Director

1636 West North Temple, Room 300

Salt Lake City, Utah 84116

(801) 533-5356

Division of Water Rights

Dee C, Hansen, State Engineer

1636 West North Temple, Room 200

Salt Lake City, Utah 84116

(801) 533-6071

Stanley Green, Directing Appropriations Engineer (801) 533-7164

Ward Wagstaff, Geothermal Specialist

(801) 533-7169

Division of State Lands

Ralph A. Miles, Director 3100 State Office Building Salt Lake City, Utah 84114

(801) 533-5381

Donald G. Prince

(801) $533-5381$

Utah Geological and Mineral Survey

Genevieve Atwood, Director

606 Black Hawk Way

Salt Lake City, Utah 84108

(801) $533-3060$

J. Wal Jace Gwynn

(801) $533-3068$

Robert Klauk

(801) 533-3065

Utah Energy Office

James Byrne, Director

825. North 300 West

Salt Lake City, Utah 84103

(801) 533-5424

Jeff Burks

(801) $533-5424$ 
Division of Environmental Health

Alvin E. Rickers, Director

150 West North Temple, Room 426

Salt Lake City, Utah 84103

(801) 533-6121

Dennis R. Dalley, Assistant Director

(801) 533-6121

Bureau of Water Pollution Control

Calvin K. Sudweeks, Director

150 West North Temple, Room 410

Salt Lake City, Utah 84103

(801) 533-6146

Earl Pierce

(801) 533-6146

Bureau of Air Quality

Brent Bradford, Director/Executive Secretary

150 West North Temple, Room 420

Salt Lake City, Utah 84103

(801) 533-6108

Montie R. Keller

(801) 533-6108

Department of Business Regulation

Eugene S. Lambert, Executive Director

330 East 400 South

Salt Lake City, Utah 84111

(801) $533-5523$

Division of Public Utilities

Ray L. Pruett, Utility Service Engineer

330 East 400 South

Salt Lake City, Utah 84111

(801) 533-5511

Utah State Tax Commission

David L. Duncan, Chairman

200 State Office Building

Salt Lake City, Utah 84114

(801) 533-4594

Robert H. Cooper, Director, State Assessed Property Tax (801) 533-5181

Federal Agencies

U.S. Geological Survey

Doug Koza, District Geothermal Supervisor

Room 2006 Administration Building

1745 West 1700 South

Salt Lake City, Utah 84104

(801) $524-4575$ 
Bureau of Land Management - Utah State Office

Bill Miller

University Club Building

136 East South Temple

Salt Lake City, Utah 84111

(801) 524-5326

U.S. Environmental Protection Agency, Region 8 Permits and Compliance Branch

1860 Lincoln Street, Suite 103

Denver, Colorado 80295

(303) $837-4335$ 
Definition of Geothermal Resources and Assignment of Administrative and Regulatory Authority

The Geothermal Resource Conservation Act, passed by the Utah legislature in 1981, defines geothermal resources and assigns regulatory authority to the Utah Division of Water Rights. The act deals specifically with high temperature resources. Appendix A contains the act in its entirety. Key definitions from the Act are as follows:

73-21-3 (5) "Geothermal resource" means: (a) the natural heat of the earth at temperatures greater than 120 degrees centigrade; and (b) the energy, in whatever form including pressure, present in resulting from, created by, or which may be extracted from that natural heat, directly or through a material medium. Geothermal resource does not include geothermal fluids. 73-21-3 (4) "Geothermal fluid" means water and steam at temperatures greater than 120 degrees centigrade naturally prsent in a geothermal system.

73-21-3 (1) "Correlative rights" mean the rights of each geothermal owner in a geothermal area to produce without waste his just and equitable share of the geothermal resource underlying the geothermal area.

73-21-3 (9) "Owner" means a person who has the right to drill into, produce, and make use of the geothermal resource.

As indicated, geothermal resources are defined by the Act as those with temperatures higher than $120^{\circ} \mathrm{C}\left(248^{\circ} \mathrm{F}\right)$. Resources at temperatures higher than $120^{\circ} \mathrm{C}$ are administered and regulated according to the provisions of the Act; hot or warm water resources at lower temperatures are regulated in accordance with Utah water law.

The Act specifies that "ownership of a geothermal resource derives from an interest in land and not from an appropriative right to geothermal fluids" (73-21-4 (1)); i.e., the possession of an appropriative water right to geothermal fluids is not sufficient to establish ownership of the rights of the resource. This provision applies to all lands within the State of Utah, including private, federal, and Indian lands. 
Section 73-21-5 specifies the enforcement authority of the Division of Water Rights and establishes procedures for enforcement and appeals through the judicial system. Section 73-21-6 states the authority of the Division of Water Rights to regulate geothermal exploration and development. Section 73-21-7 outlines the authority of the State Engineer with regard to the unitization of geothermal areas, and covers in detail the conditions, procedures, and provisions for unit agreements established by the State Engineer.

Section 73-21-8 defines the relationships between geothermal resources and water resources, and between water appropriations and appropriations of geothermal fluids. The utilization of geothermal fluids is deemed a beneficial use of the water resources of the state (73-21-8 (1)). The State Engineer may grant an appropriation of geothermal fluids on a provisional basis until well production is stabilized. Priorities exist between water rights and appropriations of geothermal fluids, but not between geothermal owners $(73-21-8(3))$. Section $73-21-9$ states that rights to geothermal resources and geothermal fluids shall be based on the principle of correlative rights. The conditions and processes for appeal are specified in Section $73-21-10$

As mentioned earlier, hot water resources below the temperature of $120 \mathrm{C}$ are regulated as water under the existing Utah water law as contained in UCA Title 73.

Leasing

Mineral leases on state lands are administered by the Board of State Lands, acting through the Division of State Lands. The laws governing the leasing of state lands are contained primarily in the UCA Title 65. Mineral leases are authorized in UCA 65-1-18, which states in part, "The State Land Board may issue mineral leases including without limitation oil, gas, and hydrocarbon leases for prospecting, exploring, developing, and producing 
minerals covering any portions of the state lands or the reserved mineral interests in state lands." The law also provides for the multiple use of state lands and give the Board authority to set the rental and royalty rates. Minimum term is 10 years with renewal provisions.

Simultaneous lease procedures are specified in UCA $65-1-45$ for 1 ands which become available for leasing through new acquisitions or because of the lapsing, for any reason, of an existing lease. Specific procedures for public notification, application and awards, and public auctions are also covered. UCA 65-1-63 provides for the unitization of leased state lands.

Exploration and Development: Water Rights

UCA 73-21-5 assigns regulatory authority for geothermal exploration and development to the Division of Water Rights. Hydrothermal resources at low and moderate temperatures are also regulated by the Division of Water Rights under Utah water law.

Geothermal Resources at High Temperatures: Geothermal resources at temperatures above $120^{\circ} \mathrm{C}\left(248^{\circ} \mathrm{F}\right)$ are regulated under the Geothermal Resource Conservation Act of 1981. Most of the important definitions have been cited in the section on definition of the resource and assignment of regulatory authority.

The purpose of the Act, as declared in Section 73-27-2, is as follows:

73-21-2. It is declared to be in the public interest to foster, encourage, and promote the discovery, development, production, utilization, and disposal of geothermal resources in the State of Utah in such manner as will prevent waste, protect correlative rights, and safeguard the natural environment and the public welfare; to authroize, encourage, and provide for the development and operation of geothermal resource properties in such manner that the maximum ultimate economic recovery of geothermal resources may be obtained through, among other things, agreements for cooperative development, production, injection, and pressure maintenance operations.

The Division of Water Rights is given the authority and responsibility to carry out these purposes by Section 73-21-5:

73-21-5. (1) The division is granted jurisdiction and authority over all persons and property, public and private, necessary to enforce 
the provisions of this chapter and shall have the power and authority to adopt and enforce rules, regulations, and orders and do whatever may reasonably be necessary to carry out this chapter.

Specifically, the Division is given the authority to require the identification of all wells (including all exploratory, production, and injection wells), and a Notice of Intent must be submitted by the developer and approved by the Division before a well may be drilled, altered or abandoned $(73-21-6)$. The Division also has authority to require the filing of surety bonds, well logs, and other reports, The Division is empowered to regulate well spacing, design, testing, operation, and abandonment.

Ownership of a geothermal resource is based on an interest in the land, rather than an appropriative right to geothermal fluids (73-21-4 (1)). In effect, the right to geothermal resources is based on ownership of the mineral rights or surface rights, which are usually obtained by direct ownership or by leasing. Because of the potential relationship between geothermal fluids and ground water resources, however, an approved application to appropriate geothermal fluids is required prior to the production of geothermal fluids from a well (73-21-8). The appropriation process for geothermal fluids is similar to that of water appropriations, and includes provisions for advertisement of the applications and the filing of protests.

The priority date for an application to appropriate geothermal fluids is the filing date. Under the law, no priorities exist between geothermal owners. However, as mentioned earlier, priorities will still exist between geothermal owners and owners of rights to water other than geothermal fluids $(73-21-8)$. Thus, the production of geothermal fluids is apportioned on the basis of correlative rights; but when conflicts arise between geothermal and non-geothermal water users, priorities would apply.

UCA Section 73-21-7 grants the Division of Water Rights the authority to unitize a geothermal area: 
(2) The division shall make an order providing for the cooperative or unit operation of part or all of a geothermal area if the division finds that a developable resource exists and that this operation is reasonably necessary to prevent waste, to protect correlative rights, or to prevent the drilling of unnecessary wells and will not reduce the ultimate economic recovery of geothermal resources.

The details of the unitization authority of the State Engineer as contained in the law are complex and specific; the reader is referred to the complete legislation, Appendix A, for that information.

Low and Moderate Temperature Resources: Utah Water Law. State Law declares that all waters in the state are public property and subject to administration by the state. Beneficial use is the basis, measure, and limit of any and all rights to the use of the water. The law provides for extensions of time of development, changes in uses, amounts or points of diversion, the splitting ("segregation") of water rights, and judicial review of state decisions. The law also requires approved applications for all wells, submission of well logs by the driller, and the submission of proof of appropriation (to validate the right).

Utah water law is much too extensive and complex for a complete discussion here, but is so important to the development of hydrothermal resources that several points should be discussed.

- There is no private ownership of water in Utah. Ownership of the water rests with the public (state), and the right to use water is granted by the state. This applies to all waters in the state, whether surface or underground, on federal, and private as well as state lands, and for all uses, whether or not water is consumed in the process.

- Under Utah water law, water rights are prioritized according to the date on which the application was filed with the Division of Water Rights. Prior water rights have a prior claim to the water granted to them, and subsequent water rights may not interfere with the earlier rights. If such interference occurs, the subsequent user must compensate the prior user for any damages.

- Beneficial use is the measure and the limit of water right; i.e., an applicant is entitled only to the amount of water he can actually produce and use in accordance with the application. The law specifically states that water rights are not to be used for speculative purposes. A water right is not perfected, even though approved, until the applicant submits proof that the water has been produced and used in accordance with the application; the amount 
of water thus produced and used (but not more than the amount specified on the application) becomes the amount of the right.

The law outlines certain requirements for the regutation of well drillers, and these requirements apply to all geothermal wells, whether exploratory or production. The statutes state that permits are required for all geothermal wells (whether or not the well is planned for production). The driller's log for the wells must be submitted to the Division of Water Rights (see also the section under Regulations which discusses this subject).

- The law grants the State Engineer the authority to issue such rules and regulations as may be necessary to the fulfilling of his responsibility. Rules and regulations governing geothermal exploration and development have been promulgated by the Division and are currently in effect. Specifics of the rules and regulations will be discussed in later sections.

Environmental Regulations

Water Quality: The primary legislation in Utah which applies to the environmental aspects of geothermal development is UCA 26-11, Sections 1-20, which deal with water pollution. The Act states public policy towards water pollution, establishes a Water Pollution Control Committee and the Bureau of Water Pollution Control within the Division of Environmental Health, establishes pollution standards, provides for the classification of surface waters, and delineates the judicial processes associated with enforcement of the law.

The water pollution statutes apply to geothermal development in cases where fluids are to be discharged to surface waters, and, by extrapolation, to reinjected fluids. The effects of these laws are discussed more completely in the section dealing with regulations.

Air quality: The Air Conservation Act, UCA 26-13, Sections 1-30, establishes an Air Conservation Committee and the Bureau of Air Quality. The Committee consists of appointed representatives of various specified sectors, including certain industries. The Comittee is empowered by the Act to adopt rules and regulations, and to establish and enforce air quality standards. Provisions for judicial review and tax exemptions are also contained in the Act. 
State Taxes

The several types of state taxes which might apply to geothermal development are listed below:

Property Taxes: The statutes which apply to property taxes are in UCA 59-(1-10). Property taxes are usually assessed and collected locally, except in the cases of public utilities or other insstances where the property is not contained within a single county. UCA 59-5(55-85) provides for a mining occupation tax on minerals extraction, but to date, that tax has not been applied to geothermal resources.

Franchise and Privilege Taxes: UCA 59-13 provides for a franchise tax on non-exempt corporations in Utah. Exempted corporations are listed in UCA 59-13-4. A tax on corporate income of $4 \%$ is specified in UCA 59-13-(65-72) for all non-exempt corporations.

Individual Income Tax: UCA 59-14A-(1-98) is the Utah Individual Income Tax Act of 1973. The tax applies to all individuals in the state.

Sales and Use Taxes: UCA 59-15 levies a sales tax of $4 \%$ on all retail sales within the state. UCA 59-16 extends a use tax of $4 \%$ on all materials stored, used or consumed within the state, effectively extending the sales tax to materials or items which are not covered by retail sales tax. Tax Incentives At present, there are no state tax incentives which apply specifically to geothermal development. For more detailed information about state taxes; the reader should contact the State Tax Comission, an attorney, accountant, or other tax specialist, or refer to publications which deal with state taxes in more detail.

District Heating and Special Uses

No legislation currently exists in Utah which specifically authorizes municipalities or other local entities to form heating districts using geothermal resources. However, UCA 73-8 authorizes the formation of metropolitan water districts, and has been interpreted to include the 
distribution of hot water for heating purposes. The statutes state that metropolitan water districts may be formed for purposes of "...municipal and domestic purposes, irrigation, power, milling, manufacturing, mining, metallurgical and any and all other beneficial uses..." (UCA 73-8-3). The chapter also spells out other necessary aspects of water districts such as the powers of the distric, elections, bonding and revenue, taxation, etc. Public Utilities

UCA title 54 contains the state laws which govern public utilities and the Public Service Commission. UCA 54-4-1 grants the commission the authority to regulate utilities in Utah:

54-4-1. The commission is hereby vested with power and jurisdiction to supervise and regulate every public utility in this state, and to supervise all of the business of every such public utility in this state, and to do all things, whether herein specifically designated or in addition thereto, which are necessary or convenient in the exercise of such power and jurisdiction; provided, however, that the department of transportation shall have jurisdiction over those safety functions transferred to it by the Department of Transportation Act.

Guidelines for regulations are given in UCA 54-3-1, which states that charges and rules must be just and reasonable, and that service must be adequate:

54-3-1. All charges made, demanded or received by any public utility, or by any two or more public utilities, for any product or commodity furnished or to be furnished, or for any service rendered or to be rendered, shall be just and reasonable. Every unjust or unreasonable charge made, demanded or received for such product or commodity or service is hereby prohibited and declared unlawful. Every public utility shall furnish, provide and maintain such service, instrumentalities, equipment and facilities as will promote the safety, health, comfort and convenience of its patrons, employees and the public, and as will be in all respects adequate, efficient, just and reasonable. All rules and regulations made by a public utility affecting or pertaining to its charges or service to the public shall be just and reasonable. The scope of definition "just and reasonable" may include, but shall not be limited to, the cost of providing service to each category of customer, economic impact of charges on each. category of customer, and on the well-being of the State of Utah; methods of reducing wide periodic variations in demand of such products, commodities or services, and the means of encouraging conservation of resources and energy. 
Definitions of the kinds of corporations which are regulated as utilities are contained in UCA 54-2-1. Electrical Corporations to be regulated as utilities are defined as follows:

54-4-21 (20) The term "electrical corporation" includes every corporation, co-operative association and person, their lessees, trustees and receivers or trustees appointed by any court whatsoever, owning, controlling, operating or managing any electric plant, or in anywise furnishing electric power, for public service or to its consumers or members for domestic, commercial or industrial use, within this state except where electricity is generated on or distributed by the producer through private property alone, i.e., property not dedicated to public use, solely for his own use, or the use of his tenants, or by an association of unit owners formed under the "condominium ownership act," chapter III, Laws of Utah, 1963 (57-8-1 to 57-8-35), and not for sale to others.

UCA 54-2-1 also states that all utilities are to be regulated by the Public Service Commission.

Certificates of Convenience and Necessity are required by UCA 54-4-25

before the construction of any new facilities by any utility, except for normal expansion within areas already serviced. UCA 54-4-26 requires approval by the commission of all new contracts by a utility:

54-4-26. Every public utility when ordered by the commission shall, before entering into any contract for construction work or for the purchase of new facilities or with respect to any other expenditures, submit such proposed contract, purchase or other expenditure to the commission for its approval; and if the commission finds that any such proposed contract, purchase or other expenditure diverts, directly or indirectly, the funds of such public utility to any of its officers or stockholders or to any corporation in which they are interested, or is not proposed in good faith for the economic benefit of such public utility, the commission shall withhold its approval of such contract, purchase or other expenditure, and may order other contracts, purchases or expenditures in lieu thereof for the legitimate purposes and economic welfare of such public utility.

UCA 54-4-31 states that the consent of the commission is required before any securities may be issued by an electrical corporation. It states that "No electrical corporation shall issue any security, nor shall any electrical corporation assume any obligation or liability as guarantor, endorser, surety or otherwise, in connection with any security of another person relating to the financing of pollution control revenue bonds, without prior written approval of the public service commission." 
District heating systems are classified as utilities under UCA 54-2-1

(16): "The term 'heat corporation' includes every corporation and person, their lessees, trustees and receivers or trustees appointed by any court whatsoever, owning, controlling, operating, or managing any heating plant for public service within this state." The law also states:

The term 'water corporation' includes every corporation and person in owning, operating or managing any water system for public service within this state; provided, this shall not apply to private irrigation companies engaged in distributing water only to their stockholders; nor shall the term include towns, cities, counties, water conservancy districts, improvement districts, or other governmental units created or organized under any general or special law of this state (UCA 54-2-i (26)).

Court decisions have determined that municipalities, counties, improvement districts, cooperative associations, and non-profit organizations run for the benefit for their members or constituents are excluded from regulation by the Public Service Commission.

UCA 54-3 outlines the duties of public utilities and the regulatory authority. It contains provisions for just and fair charges and requires that schedules of rates be filed with the commission. UCA 54-4 deals with hearings before the commission. It empowers the commission to hold hearings to set or fix rate schedules, approve or disapprove improvements or repairs, and requires utilities to provide safety apparatuses to protect the public. It gives the commission the authority to valuate the property of public utilities, and to fix proper rates of depreciation. Certificates of convenience and necessity are required prior to any construction or operation, and contracts which call for expenditures must be approved by the commission. 


\section{STATE REGULATIONS}

\section{Leasing of State Lands}

A lease from the State of Utah must be obtained in order to develop geothermal resources on state lands. The lease includes the rights to explore and develop the resource, and secures the rights to the resource for the developer. State geothermal leases are issued as mineral leases, and the general mineral lease regulations apply to geothermal leases. In addition, a few special stipulations are attached to geothermal leases in particular.

Application Forms and Fees: Applications must be submitted on the forms provided by the Division of State Lands. The fee for a mineral lease application is $\$ 10.00$. The first year's rental of $\$ 1.00$ per acre or fractional part thereof per annum must be submitted with the application. If the lease is rejected, the application fee is retained by the state and the rental is returned to the applicant.

Lease size: In general, the minimum size of a lease is a quarter-quarter section (usually about 40 acres), and the maximum size is four sections, or 2,560 acres, if the area is in a compact block.

Simultaneous Filing Procedures: Leases are issued to the applicant with the earliest filing. However, when lands become newly available for lease, because of new purchases, relinquished leases, or any other reason, they are leased under the simultaneous filing procedures. Under this procedure, notices of intent to lease are posted for 15 working days, during which time, bids are accepted for the tracts. Bids are submitted in sealed envelopes and must be at least equal to the rental rate; the bid amount is considered the first year's rental. Bids are opened on the first business day following the end of the 15 day bidding period; the notices are timed so that all bid openings occur on the last Monday of each month. In case of identical bids, the right to lease is determined by a public drawing. Deposits minus filing fees are returned to unsuccessful bidders. 
Geothermal Leases: Because of the ambiguity in the law about the nature of geothermal resources, geotherinal leases will only be issued for lands to which the state owns both mineral and surface rights, unless the lessee signs the "Addendum to Geothermal State Lease and Agreement." The Addendum essentially states that the State of Utah issues the lease as a mineral lease; if the State Supreme Court should rule that geothermal resources are not part of the mineral estate, then the state assumes no responsibility to the lessee for refunds, except for royalties already paid on that portion of the resource adjudged not to be part of the mineral estate.

Bonding and Assignments: Before the lessee can pursue any operations on the leased land, a bond must be filed with the Division of State Lands. A statewide exploration bond of $\$ 25,000$ may be filed, or an individual project bond for an amount determined by the Division may be filed. Leases and overriding royalties may be subleased or assigned.

Term: The initial term of state geothermal leases is ten years, and may be extended as long as the leased land is in production. The lessee is granted the rights of access, exploration, and production as well as the associated rights of construction and improvement.

Rental: The annual rental of $\$ 1.00$ per acre per annum must be paid at the beginning of each rental year. Royalties are 10 percent of the gross proceeds received from the sale of those products, or 10 percent of the fair market value where the products are utilized but not directly sold.

Special Provisions: Two important provisions in the geothermal lease agreement are the development provision and the offset well protection provision. The development provision commits the developer to commence drilling operations on the leasehold within five years from the date of the lease issuance and to pursue diligent exploration activities until products are discovered. The initial period may be extended an additional five years upon written application. The section requires that drilling plans be 
submitted to the Division of State Lands at least one month prior to the commencement of drilling, that adequate measures be taken to make the well safe and protect the environment, and that the lessee pursue full development once the resource is discovered.

The offset well drainage protection provision commits the lessee to protect the leasehold from drainage by offset wells on adjacent lands not owned by the state. Orainage from the leasehold is assumed to occur due to nearby wells on other lands unless the lessee proves otherwise. The primary mode of protection against drainage would be by wells drilled by the lessee on the leasehold, which would cause a compensating counter drainage.

Other provisions require the lessee to notify the state before the abandonment of any wells, and reserve to the state the right to retain use of the well for other purposes after the lessee has abandoned the prospect; require the developer to comply with Utah water law and obtain necessary permits and approvals from the Division of Water Rights; provide for the unitization of state and other lands; and specify the terms and conditions of assignments, default, and surrender of lease.

The complete regulations for mineral leases in general are contained in "State of Utah Rules and Regulations Governing the Issuance of Mineral Leases," available from the Division of State Lands. The "Geothermal Steam Lease and Agreement," also available from the Division of State Lands, contains many requirements applicable to geothermal leases in particular. Exploration and Development

The Division of Water Rights is the lead agency for the regulation of geothermal exploratory drilling. The various stages of exploration and development are discussed below.

Exploration Drilling: All exploratory wells, including large exploratory wells, temperature gradient holes, stratigraphic tests, and 
observation wells require approval from the Division of Water Rights. Permits are required for all exploratory drilling, whether or not the well will be used for production.

Test Well Permits: Temperature gradient wells, stratigraphic test wells, observation wells, and other wells which will not be used for production are usually approved in accordance with Utah water law as test wells. For test wells, a letter application is submitted to the Division of Water Rights. A single application may cover a single well or a group of wells, but the wells in a given application should be in the same hydrographic province. The application letter should contain the pertinent information including the well names and numbers, the exact locations of the wells, the expected depth and size of the wells, the land status of the wells, and the purpose or type of well to be drilled.

Accompanying the letter of application should be a Plan of Operations. The Plan of Operations should be much more detailed than the letter application. The information requirements for the Plan of Operation are found in the "Division of Water Right Rules and Regulations for wells Used for the Discovery and Production of Geothermal Energy in the Stat of Utah," and are as follows:

a. Location, elevation, and layout

b. Lease identification and well number

c. Tools and equipment description, including maximum capacity and depth rating

d. Expected depth and geology

e. Drilling, mud, and casing program

f. Blow-out prevention equipment installation and testing

g. Logging, coring, and testing program

h. Methods for disposal of waste materials 
i. Environmental considerations

j. Emergency procedures

k. Other information which the State Engineer may require

These requirements are much the same as those of Plans of Operation required for drilling on federal land; if the Plan of Operation submitted to the federal government contains the information listed above, usually it is acceptable for submission to the state.

The time required for approval of a test well permit is minimal, usually ranging from a few days to two weeks. The permits are usually valid for a period of six months, and may be renewed at any time by a letter : request.

Other provisions of Utah water law apply to the drilling of exploratory wells. The driller must be licensed by the state and must comply with all provisions of the "Regulations for Water Well Drillers," issued by the Division of Water Rights, unless a specific variance is granted in the text of the test well approval letter. The driller must notify the Division at the commencement of drilling operations and must submit a driller's log at the conclusion of the drilling. Temperature, geologic, and hydrologic data from each well must be submitted to the State Engineer; this information is held confidential by the Division.

In the past, some geothermal exploration, including temperature gradient surveys and open observation wells, has been conducted without state permits and without notifying the proper state agencies. The rationale for these activities has been that since the wells were not intended for the production of water, no drilling permits were necessary. This is directly contrary to the laws of the State of Utah. All drilling, whether for exploration or production of geothermal resources, falls under the regulatory responsibility of the Division of Water Rights. Questions about the applicability of the law should be directed to the livision. 
Production Drilling: Wells drilled under test well permits may be used later as production wells if the water appropriation application so specifies. In any case, before any well can be used for production, a valid water right must be obtained. The right to use the water, which is owned by the state, is granted to the applicant via the approved application. A water right for geothermal use is subject to all of the restrictions and requirements of a standard water right.

Water Rights: Water right applications are filed on the standard form distributed by the Division of Water Rights. At the time of filing, the water right application is marked with the date and time, which becomes the basis for the priority of the application.

The application is processed through the office and is advertised in a local paper for three consecutive weeks. During the advertising period and for a period of 30 days following its close, protests are received by the Division. At the end of the protest period, the applicant is given the opportunity to respond to the protests. Unless the protests are withdrawn, the State Engineer will conduct a public hearing to consider the protests. The State Engineer may also conduct hearings if he considers it desireable. The hearing provides a forum for the applicant and protestant(s) to present the facts of the case, as they see them; the hearing is only for purposes of reviewing facts and data, and not for the decision itself. Following the hearing, the State Engineer makes a decision, taking into account recommendations by the Area Engineer and the Appropriations Engineer.

The initial term of the approved application is three to four years. During this time, the applicant must pursue development of the water right by drilling the well(s) and using the water. At the end of this period, the proof of use is due; the applicant must demonstrate that he has produced the water and put it to the beneficial use specified in the application. If the 
applicant has a valid reason for not developing, i.e., has shown diligence and/or has reasonable cause for delay, he may file for an extension of the proof period. In any case, the amount of water which becomes the basis of the right is the amount on which the applicant actually "proves up," as long as it is equal to or less than the amount specified in the original filing. The water right is perfected when the State Engineer reviews the proof and certificates the application. If the applicant chooses, and if the area has been adjudicated by court decree, the Division of Water Rights will verify the use and amount under the "election" procedure.

Consumptive and Non-Consumptive Water Rights: Water Rights may be "consumptive" or "non-consumptive." A consumptive right allows the user to utilize the water without returning the water in its original amount (or sometimes quality) to the body of water from which it was diverted. Irrigation, municipal, domestic, and process water uses are examples of consumptive rights. When the water is returned in its full quantity to the original source, the use may be deemed non-consumptive; examples are hydroelectric plants on rivers or geothermal systems where spent fluids are reinjected. Many areas of Utah have been fully appropriated, i.e., the State Engineer has determined that no more water may be withdrawn from the groundwater aquifers without seriously depleting the groundwater supplies and affecting existing users. In these area, consumptive rights will probably not be granted. A Geothermal developer might be granted a non-consumptive right, with reinjection required, so that he can use the water for energy purposes without depleting the groundwater supply. In some cases, the developer might buy existing consumptive rights in order to acquire water for consumptive use.

Segregations: A water right application may be divided into separate applications which are then processed independently. This process is called "segregation." The segregation assumes the same priority as the parent 
application, whether the segregation is filed before or after the approval of the parent application.

Changes: The place and nature of use or point of diversion of a water right application may be changed by approval from the State Engineer. Application must be made on the standard change forms of the Division of Water Rights. The amount of water used may also be changed using a change application, if it is less than the original application; however, the usual practice is to segregate part of the original application and file the change on the portion.

Drilling Requirements: Drilling of geothermal exploration and production wells must be in accordance with the "Rules and Regulations of the Division of Water Rights for Wells Used for the Discovery and Production of Geothermal Energy in the State of Utah." The regulations specify that wells must be cased in such a manner as to protect both the surface and subsurface environments, and specifies casing lengths and cementing requirements for different situations. The regulations specify mud return monitoring requirements. Blow-out prevention equipment requirements are also included for cases where air or mud is used as the drilling fluid.

Records: The Rules and Regulations require that accurate records, be maintained during drilling and filed with the Division of Water Rights. Records which must be submitted to the Division include drilling logs and core record, well history, well summary report, production records, injection records, and electric logs and directional surveys (if conducted). All of these records are held confidential by the Division.

Injection Wells: In most cases, the water right application should include provisions for injection wells, and approval of the application implies approval of the injection system. The Rules and Regulations require that prospective injection wells be tested to demonstrate the integrity of the 
casing, and that after injection has commenced, that sufficient surveys be conducted to demonstrate that the injected fluid is confined to the intended injection zone.

Abandonment and Sealing: The Rules and Regulations establish requirements for proper abandonment to prevent interzonal migration of fluids and hazards to the public. The Rules and Regulations specify the plugging and cementing requirements.

Environmental Regulations

The Resource Development Coordinating Committee (RDCC) is composed of representatives of all state agencies which might be involved in environmental permits or clearances. The RDCC acts as a clearing house for environmental permits by coordinating cases where the developer must deal with more than one agency. The RDCC exercises no regulatory authority, but does serve in an advisory capacity to the Governor and to state agencies.

Most of the general environmental permitting is done by the Division of Environmental Health. The recommended procedure for obtaining approvals from the Division is to schedule a pre-design conference, which is an ad hoc meeting between the developer and representatives from the Division and its various bureaus. The purpose of the pre-design conference is to determine which permits will be required; to inform the applicant about preliminary details of health standards, construction permit requirements, and approval procedures; and to coordinate the various permitting processes by the agencies involved.

The pre-design conference is set up such that it would be best utilized prior to any design activities, since the potential impacts, problems and acceptability of some of the various alternataives can be discussed in a constructive atmosphere. Because the statutory authority for environmental permits is quite complex, the pre-design conference gives the developer a more comprehensive insight into the permit requirements. 
A list of the various bureaus of the Division of Environmental Health Services is included at the end of this section. In practice, a geothermal developer will probably be most concerned with two of the Bureaus, the Bureau of Water Pollution Control and the Bureau of Air Quality.

Water Pollution Control: The Bureau of Water Pollution Control requires the submission of plans for all installations which might produce liquid wastes or other wastes capable of polluting water, as well as facilities designed to control water pollution. The Bureau oversees both surface discharge and underground injection, and thus all facilities utilizing geothermal fluids at the surface would need approval by the Bureau. The approval is in the form of a construction permit, which is issued when the project plans have been reviewed, corrected, and approved.

The law establishes anti-degradation policies for most surface waters, and the federal Safe Drinking Water Act (SDWA) effectively extends this policy to groundwater aquifers. The anti-degredation policy requires that no discharges into most streams or groundwater aquifers will be permitted if they result in any deterioration of the existing water quality of the stream or aquifer. This means that discharges of spent geothermal fluids, for instance, will not be allowed either into surface waters or underground waters if the water quality of the stream or aquifer is significantly better than the quality of the discharged fluids. In effect, this will limit the location of injection wells and complicate surface discharge methods.

Water quality standards for the various classifications of waters within the state are summarized in Appendix B. The Utah Water Pollution Control Committee has grouped the various surface waters of the state into classes. Lists of the waters with their classifications are available from the Bureau of Water Pollution Control.

Surface Discharges: For discharges to the surface waters of the state, permits must be obtained from both the Utah Bureau of Water Pollution Control 
and the U.S. Environmental Protection Agency (EPA). The reason why two permits are required is that the state has not yet enacted water quality regulations which are acceptable to the EPA; and thus has not assumed primacy in the permitting process. The State permits are in the form of the construction permit previously mentioned. The federal permits are the standard NPDES discharge permits issued by the EPA: application is made to the regional EPA office in Denver (see the list of agencies). These permits are required both for discharges during the operating phase of the project and for discharges during testing of the resource, if the discharge enters a classified stream or waterway.

Injection: In Utah, two agencies exercise permitting authority for geothermal injection wells: the Bureau of Water Pollution Control, and the Division of Water Rights. By virtue of a letter of agreement, the Division of Water Rights has assumed a lead role in issuing geothermal permits as long as the applicant complies with the standards and regulations of the Bureau of Water Pollution Control. The concerns of the Bureau are mainly water quality considerations, whereas the Division of Water Rights is concerned with hydrologic considerations as well. Injection wells must be located so that aquifers with a potential for domestic use are not contaminated. As mentioned earlier, in many cases, injection is encouraged or required in order to maintain water levels in heavily-used aquifers. Both the Bureau of Water Pollution Control and the Division of Water Rights must approve plans for injection wells; the applicant should contact the Division of Water Rights, which will coordinate the approvals of the two agencies.

Air Quality: Pursuant to the Air Conservation Act, the Air Conservation Committee has adopted rules and regulations and is active in establishing and enforcing air quality standards. The Bureau of Air Quality 
issues combined construction and operation permits for facilities which might emit any substance to the atmosphere. Submission of plans is required. If there are no apparent adverse air quality impacts, the project plans will be held for a 30 day public comment period. A hearing will be held if someone requests it within fifteen days of the beginning of the comment period. When the comment period has expired, the Executive Secretary of the Utah Air Conservation Committee will take all of the submitted comments and make a final decision as to whether or not an air quality approval letter should be issued.

Air quality regulations will probably not affect small direct utilization projects, but may affect larger projects, particularly electrical installations, depending on the chemical content of the water and the design of the plant. Flashed-steam systems will usually have atmospheric emissions, whereas binary or closed-loop systems probably will not.

Other Agencies and Permits: The other Bureaus within the Division of Environmental Health are coordinated by the Division, especially via the pre-design conference. If the nature of the project is such that additional permits are required from the other Bureaus, approval by any one Bureau is contingent upon approval by the others - i.e., the full approval is withheld until all of the appropriate bureaus have issued their individual approvals. The Bureaus of the Division of Environmental Health are as follows:

\footnotetext{
- Bureau of Air Quality

- Bureau of Radiation

- Bureau of Sanitation

- Bureau of Solid Waste Management

- Bureau of Water Pollution Control

- Bureau of Public Water Supplies
} 
Public Utility Regulations.

Apparently, geothermal developers which sell heat or distribute water to the public in general are classified as public utilities and are subject to regulation by the PSC. The size of the company or the number of customers does not affect its classification as a utility. The PSC determines the allowable rate of return for the company, based on a fair return for the particualr type of business. The utility is allowed to recoup all costs and expenses, and the rate schedule reflects the allowed rate of return plus costs to the company.

The time required for the rate approval will depend on the amount of data which must be gathered; thus a large utility will have a longer approval time than a smaller utility. Municipalities, improvement districts, cooperative associations and other user-owned or non-profit companies are exempt from public utility regulation. Geothermal distributors should examine the advantages and disadvantages of public utility status and investigate the various alternatives which might be available. Local Permits and Regulations:

In most cases, county and local governments have permitting and regulatory requirements which apply to geothermal development within the ir jurisdication. Such permits may be related to zoning, business licenses, building permits, etc. Because the requirements for these permits vary widely, they are not discussed in detail in this report; a prospective developer should consult the appropriate agencies in the respective area for information on local permits. 


\section{STATE INFORMATION AND ASSISTANCE}

Utah Energy Office

The Utah Energy Office was created by Executive Order by Governor Matheson in 1977 and was made part of the Department of Natural Resources and Energy in 1981. The Energy Office was created to advise the Governor in energy-related matters and to implement his energy policies within the state. It was also created to provide advisory and technical support to the Energy Conservation and Development Council, which in turn acts in an advisory and coordinating capacity for the Governor. In connection with its other responsibilities, the Energy Office handles a number of federal contracts for the state and manages state energy programs.

State funding for geothermal demonstration projects has been administered through the Energy Office. The State Prison geothermal heating project, for example, was funded under a cost-share agreement between the U.S. Department of Energy (DOE) and the State of Utah; the Utah Energy Office managed the project for the State.

The Energy Office has administered a number of DOE funded conservation programs which are oriented toward the public. Among these are general energy information and some technical guidance programs, information on funding sources, and coordination of state interaction with proposed energy projects. The Energy Office deals with a broad spectrum of energy sources; its involvement in geothermal energy has been limited to the Utah State Prison geothermal space heating project. Utah Geological and Mineral Survey

The Utah Geological and Mineral Survey (UGMS) was established by statute to gather and publish geological and technical information. The UGMS, 
a Division of the Department of Natural Resources, is a professional research agency, and conducts specific geologic investigations for the state. A wide range of publications and maps, both general and specific, are available to the public through the UGMS.

State Coupled Geothermal Resources Assessment Program: The Research Geology Section of the UGMS conducts the U.S. DOE sponsored State Coupled Resource Assessment Program for. Utah. The objective of this program is to gather and publish technical data on general geothermal areas and specific geothermal sites. As part of the State Coupled Program, the UGMS has conducted investigations at a number of geothermal sites, primarily along the Wasatch Front. These investigations have included exploratory drilling and preliminary geologic analysis at several hot springs in Northern Utah. The results of these investigations are listed in the section on Publications and are available through the UGMS Information and Sales.

The State Coupled Geothermal Program compiled data for the map "Geothermal Resources of Utah" (1980), which was prepared and published by the UGMS, the U.S. DOE, and the U.S. National Oceanic and Atmospheric Administration (NOAA). The map shows warm and hot water wells and springs in Utah, and includes a tabulation of specific data for each site. General areas which are potentially favorable for the discovery and development of low temperature resources $\left(90^{\circ} \mathrm{C}\left(194^{\circ} \mathrm{F}\right)\right.$ and lower $)$ are also indicated. The maps are available directly from the UGMS.

The State Coupled Geothermal Program offers information assistance on geothermal resources to prospective users and developers in Utah. It also coordinates between the prospective developer and the geologic/geophysical portion of the U.S. DOE technical assistance program. Those interested in available geologic information should contact the geothermal program at the UGMS. 
Geothermal Commercialization Program

The Utah Division of Water Rights has a contractual agreement with the U.S. DOE to conduct the Geothermal Commercialization Program for Utah. The purposes of this program are to provide planning and utilization data to state agencies and the U.S. DOE; to provide information services to the state and to prospective users; to perform anaylsis of institutional aspects of geothermal development; to provide limited technical assistance to prospective users; and to provide information on various governmental funding and assistance sources. The Commercialization Program is set up specifically to assist prospective users and developers of geothermal resources; those desiring information or assistance should contact the geothermal office at the Division of Water Rights.

Industrial Promotion Division

The Industrial Promotion Division of the Department of Development Services provides assistance to industries and businesses seeking to locate or relocate facilities within Utah. The Division actively solicits industry and businesses to establish in Utah. The services provided by the Division of Industrial Promotion include extensive demographic and economic information, advice on various funding and financing alternatives (particularly state or federal grant or loan sources), and contacts with state and local agencies which might be involved with a given development. Multi-County Economic Development Agencies

Multi-County planning and economic development agencies work with communities and businesses within subareas of the state by providing background information and by assisting with grant proposals and other funding mechanisms. Their objective is to promote economic and social growth and strength within the areas they serve and to provide staff support which would not otherwise be available to county and community governments. The regional agencies work directly with individual municipalities and counties as well as individual businesses. 
FEDERAL REGULATIONS AND PERMITTING PROCEDURES

Geothermal exploration and development on federal and private lands are generally subject to state regulations, (except for those regulations which are part of state lease agreements) as well as the federal regulations. A brief summary of federal regulations affecting development on federal land is given below.

Principal Agencies:

In Utah, the federal agencies which are most directly involved in the regulation of geothermal development (on federal lands) are the Bureau of Land Management (BLM) and the U.S. Geological Survey (USGS) of the Department of the Interior, and the U.S. Forest Service (USFS) of the Department of Agriculture. On Indian Lands, the Bureau of Indian Affairs is involved. Other federal agencies which are involved with geothermal development but not in a direct regulatory capacity are the U.S. Department of Energy (DOE), the U.S. Fish and Wildlife Service (USFWS), and the U.S. Environmental Protection Agency (EPA).

\section{Pre-lease Exploration:}

Non-surface-disturbing exploratory activities may be conducted on federal lands not leased by the developer when such activities are approved by the surface management agency (usually the BLM or USFS). Geochemical and geological surveys, geophysical investigations such as gravity or ground magnetic surveys, temperature gradient drilling to depths of 500 feet or less, and other preliminary exploration activities may be conducted under a casual use permit. Application for the permit is made directly to the management agency and approval time is 30 days or less.

Leasing.

Geothermal leases on federal lands are obtained by application to the BLM. Applications are processed as either competitive or non-competitive leases. 
Non Competitive Leases: The non-competitive lease procedure is the simplest and most direct. When a lease application is filed with the BLM, it * is referred to the surface management agency if the land is not under BLM jurisdiction. The surface management agency consults with the other agencies involved, principally the USGS, to schedule the Environmental Assessment (EA). The EA is then conducted by the surface management agency and used to determine if a full scale Environmental Impact Statement (EIS) is necessary. The results of the EA are incorporated into the lease stipulations. The lease application is then sent to the regional USGS office to determine if it still qualifies as a non-competitive lease, i.e., If other lease applications for the same land have been filed. If it is still non-competitive, it is sent back to the BLM for approval, and the lease is issued subject to the lease stipulations imposed as a result of the EA. If the application does not qualify as a non-competitive lease, a lease sale is scheduled and the lease follows the competitive lease procedure discussed in the next section. Currentiy, non-competitive leases in Utah are issued in about eight months, including about five months for the EA and about three months for subsequent administrative work. If problems arise, particualrly in connection with the $E A$, the approval process may take longer.

Competitive Leases: Under the provisions of the Geothermal Steam Act, a parcel of 1 and may be declared a known Geothermal Resources Area (KGRA) for three reasons: 1) geologic indications of a resource at the site; 2) discovery of geothermal resources on nearby lands; and 3) competitive interest in the land by developers, i.e., simultaneous filing by two or more developers for the same land.

When a parcel of land is designated a KGRA, a lease sale is scheduled by the surface management agency in conjunction with the USGS and other agencies. In the meantime, an $E A$ is conducted; the results of the $E A$ are 
used to determine if an EIS is required. If no EIS is necessary, the lease stipulations are drawn-up, incorporating the results of the EA and recommendations by the USGS and other involved agencies. The lease sale is then announced by the BLM and bids are accepted. Bids must include the $\$ 1.00$ per acre first year fee plus a bonus. The lease is awarded to the highest bidder.

Competitive and non-competitive leases are issued for a ten-year initial term with provisions for renewal. Lease rentals are $\$ 1.00$ per acre per year for the first five years (plus the first year bonus bid for competitive leases); beginning with the sixth year, the rental increases at a rate of $\$ 1.00$ per acre per year, to the tenth year. The royalty on the energy consumed or sold by the lessee is a minimum of 10 percent and a maximum of 15 percent.

Post Lease Exploration.

After a lease has been issued, the lessee must still obtain permits from the USGS for exploratory activities on the leasehold. A Casual use permit may be issued authorizing non-surface-disturbing activities such as geological and geophysical surveys, soil, rock, and water sampling, shallow temperature gradient holes, etc. Casual use permits are usually issued within 30 days. Application for the permit is made through a Notice of Intent (NOI). In order to conduct more intensive exploratory activities, the lessee must submit a Plan of Operations to the USGS, and an application for a geothermal drilling permit if drilling is planned. The plan of operation must contain detailed descriptions of the proposed activities; exact locations where disturbances will occur; plans for the mitigation of the environmental impacts; and detailed plans for access, waste disposal, progress monitoring, and the emergency safety procedures. When the plan of operation is submitted, an EA is conducted by the USGS on the specific sites propsed for the activity; 
following the EA, comments are solicited from other involved agencies and the permit is approved subject to the stipulations developed through the EA process. Plans of Operation are required for exploration, development, injection, utilization, and production of the resource.

Federal regulations require that at least one year of baseline environmental data be gathered on the leasehold and submitted to the USGS before the submission of a Plan of Production. A Plan of Baseline Data Collection outlining the data gathering program must be submitted to the USGS and approved prior to the commencement of the program. Baseline environmental data may be obtained from other sources if it is available.

Most plans of operation require three to five months for approval, and some of the more extensive plans may have longer approval times.

The siting of major facilities is done directly by the surface management agency (BLM or USFS) in cooperation with the USGS. Small experimental or research plants are frequently exempt from the siting requirement. Usually, siting of large facilities will necessitate extensive environmental investigations. No siting permits have yet been approved for federal lands, but the approval time is estimated to be up to 18 months. 


\section{AGENCIES AND PERMITS}

As with most natural resources, a number of permits are required before geothermal resources may be developed or used. Table 2 is a general summary of some of the permitting requirements for geothermal development. Of course, permitting requirements will vary between individual projects, particularly with respect to the data required for submission and the time necessary for approval; for these reasons a developer should consult the respective agencies directly for permitting information. 
Agency

County Agencies

County Planning Commission

County Clerk

County Commission or Heal th Dept.

\section{State Agencies}

Division of State Lands

Lease of state lands

Right-of-way for geophysical surveys

Special use permit

Encroachment permits

enforcement Building inspection

\section{Required Prior to:}

Depends on County

Sale of electricity or Varies commencement of business

Use of buildings

Varies

Exploration or use of state lands

\section{Few days to 2-3 weeks}

\section{Geophysical surveys on state lands}

\section{Usually 1-2 weeks}

Surface disturbance (construction of plant)

Not known-possibly about 2 months

Few days

\section{Comments}

Already accomplished for geothermal in some counties
Department of Transportation
Use of state highway lands for utility lines
May be competitive or noncompetitive; competitive procedure does not add significantly to the process time

Access to state lands for non-surface disturbing investigations

Not yet applied in Utah Not

Necessary for use of or crossing of state highway rights-of-way with utility lines such as power lines, water mains, sewage or drain pipes, etc. 


\section{Agency}

Division of Water Rights

$\underset{\infty}{\omega}$

\section{Permit}

Permits for thermal gradient wells

Permit for drilling exploratory (test) wells
Permit for reservoir test

Appropriation of water

\section{Appropriation of geothermal water rights}

Production and injection wells

Water well drillers permit

\section{Required Prior to:}

Drilling of thermal gradient wells

Drilling of exploratory wells

Extended reservoir tests

Production or use of water $\left(<120^{\circ} \mathrm{C}\right)$

\section{Production or use of geothermal fluids $\left(>120^{\circ} \mathrm{C}\right)$}

Drilling of production and injection wells

Drilling of any exploratory or development wells, including thermal gradient wells
Estimated Time

for Issuance

\section{Few days to few weeks \\ Few days to \\ few weeks \\ Letter of approval issued \\ Test well letter issued with stipulations}

Few days

\section{6 months or longer}

\section{6 months or Tonger}

Few days to few weeks

\section{Comments}

Low temperature resources $\left(<120^{\circ} \mathrm{C}\right)$ are administered under water law. Approval time may depend on the developer

Same basic prodedure as water right appropriations. High temperature resources $\left(>120^{\circ} \mathrm{C}\right)$ regulated according to Geothermal Resources Conservation Act.

Covered by appropriation of water or geothermal fluids if included in the application and the plan of operations

Required for drillers. Drillers bond required; issuance may take a few days to a week in addition to the time required to post bond 
TABLE 2. AGENCIES AND PERMITS (CONTINUED)

\begin{tabular}{|c|c|c|c|}
\hline Agency & & Permit & Required Prior to: \\
\hline $\begin{array}{l}\text { Division of } \\
\text { ronmental }\end{array}$ & $\begin{array}{l}\text { Envi- } \\
\text { Health }\end{array}$ & $\begin{array}{l}\text { Pre-planning } \\
\text { workshop }\end{array}$ & Environmental pe \\
\hline \multirow[t]{3}{*}{$\begin{array}{l}\text { Bureau of } \\
\text { Pollution }\end{array}$} & $\begin{array}{l}\text { Water } \\
\text { Control }\end{array}$ & $\begin{array}{l}\text { Construction Permit } \\
\text { for fluid discharge }\end{array}$ & $\begin{array}{c}\text { Construction or } \\
\text { operation }\end{array}$ \\
\hline & & (Surface Discharge) & Operation \\
\hline & & (Injection) & Operation \\
\hline $\begin{array}{l}\text { Bureau of } \\
\text { Quality }\end{array}$ & Air & Approval Order & $\begin{array}{l}\text { Construction and } \\
\text { operation }\end{array}$ \\
\hline
\end{tabular}
Quality

$$
\text { operation }
$$

\section{Bureau of Water}

Estimated Time

\section{mitting}

\begin{abstract}
Department of Business
\end{abstract}

Regulation

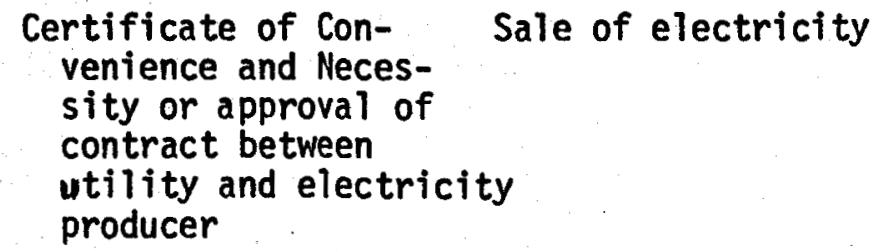

for Issuance

\section{Comments}

Coordination of initial contact with various Bureaus within the Division

About 2 months

Permits must be approved by Water Pollution Control Committee, coordinated by the Bureau of Water Pollution Control

About 2 months Must be obtained in addition to U.S. EPA NPDES permit

Coordinated with the Division of Water Rights

Usually about For discharges with less than 3 months 250 tons per year of a criteria substance, a permit for discharges to the atmospere must be approved by the . Executive Secretary of the Utah Air Conservation Committee

Usually about For discharges equal to or 3 months greater than 250 tons per year of a criteria substance, a PSD permit must be obtained from the Bureau of Air Quality

3 to 4 months
Certificate of Convenience and Necessity if utility owns plant; if utility buys power, approval of sale contract is required




\section{Agency}

Department of

Business Regula-

tion (continued)

\section{Federal Agencies}

\section{Bureau of Land}

Management

䓃
Permit
Certificate of Con- venience and Necessity

Required Prior to:

Sale of heat

(district heating)
Estimated Time for Issuance

3 to 6 months

\section{Comments}

Required if classified as a public utility

Includes geophysical/geological exploration, thermal gradient surveys, etc.; agency has 30 days to act on application on lands not leased by the applicant

Leases--BLM and USFS lands

Conduct EA

Conduct KGRA lease sales

Issues lease

Plant siting permit

Plant Construction

Post-lease joint approval with USGS of plans of operation

U.S. Forest Service Special use permit for pre-lease operations

Exploratory activities on lands not leased by applicant

30 days otal: abo
months

Not known

None approved so far

Approval based on site-specific examinations

ease includes rights to develop the resource

About 5 months

1: about 8

Includes geophysical/geological exploration, thermal gradient surveys, etc.; agency has 30 days to act on application

Up to 17 months Lease includes rights to or longer
Major exploratory
activities lands develop the resource 
TABLE 2. AGENCIES AND PERMITS (CONTINUED)

Agency

U.S. Forest Service

-

-

U.S. Geological Survey (continued)

\section{Permit}

Conducts EA

Conducts KGRA lease sales

Approves lease

Post-lease joint approval with USGS

of plans of operation
Estimated Time

Required Prior to:

\section{Comments}

Administers terms of leases

Permits for exploratory activities
Non-surface disturbing activities on lands leased by the applicant

Plans of Operation
Plan of Exploration Surface disturbing activities (deep drilling)

Categorical Exclusion Review

Plan of Environmental Base Line Data

Gathering of required Collection
30 days

Includes most geological and geophysical surveys, thermal gradient surveys, etc.; USGS has 30 days to act on permit

Plans of operation are site specific

Up to 1 year for Subsequent operations may be initial approval; less for subsequent operations

about 90 days base line data
3 to 5 months

\section{approved with a Categorical} Exclusion Review (CER)

May be used for any Plan of Operation in any area where an EAR has already been written; site specific investigations are conducted, but no report is written

Must be approved before base line program begins 


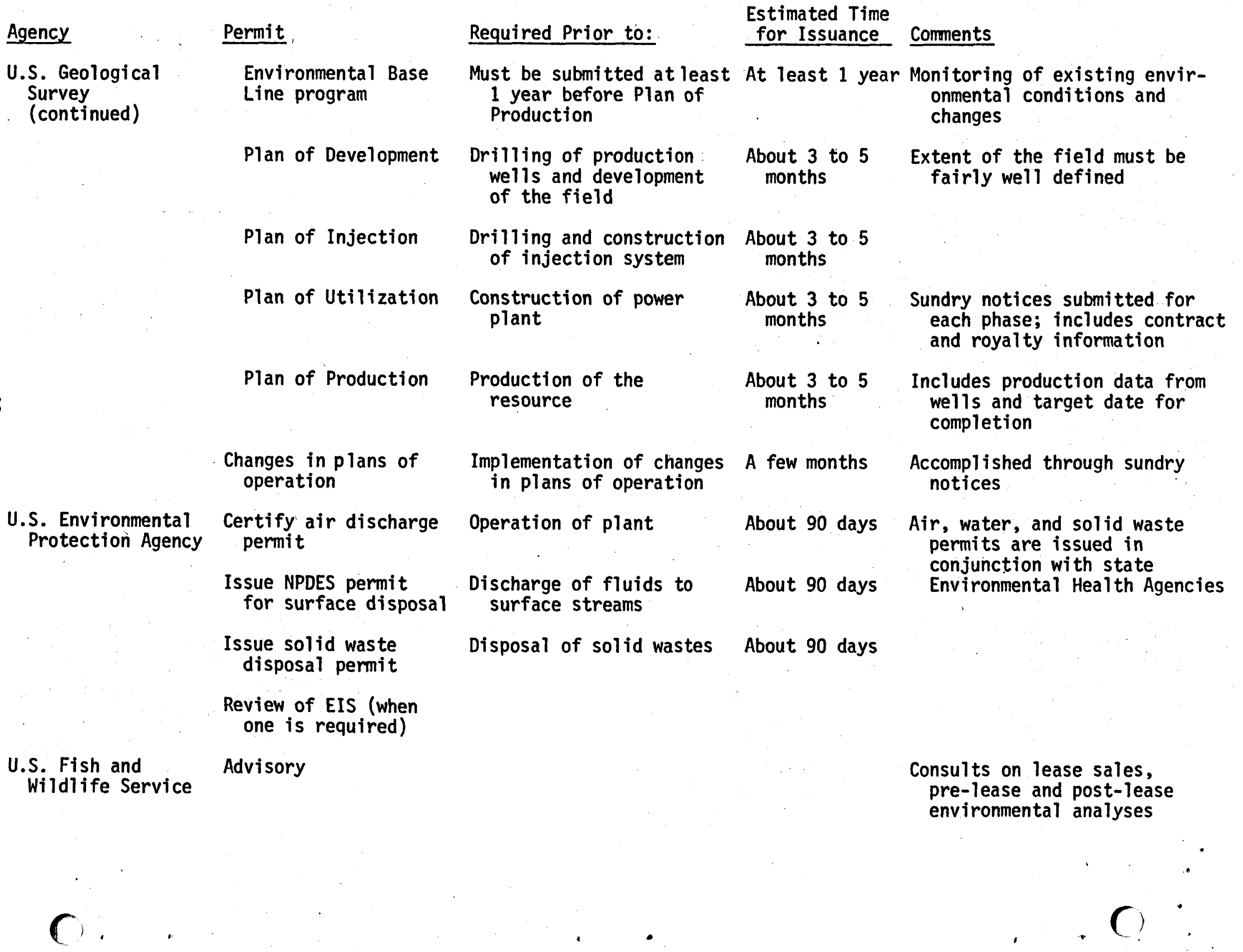




\section{Procedural Flow Charts \\ This section contains flow charts for some of the general activities}

and permitting procedures which might be followed by a geothermal developer. These charts are intended to give a general idea of the procedures and steps involved in a geothermal development; a given project may vary widely from the steps indicated in the charts. The applicant should consult the respective agency for further information and clarification.

The following is a list of the flow charts included in this section:

1. State Leases - Noncompetitive

2. State Leases - Simultaneous Filing (Competitive)

3. State Environmental Health Permits - Bureau of Water Pollution Control

4. Detailed Procedure for the Granting of Water Rights

5. Typical Procedure for Major Development on BLM Land

6. Typical Resource Assessment Program for Low or Moderate Temperature Resources

7. Typical Procedure for the Development of Low or Moderate Temperature Resources 
STATE LEASES - NON-COMPETITIVE

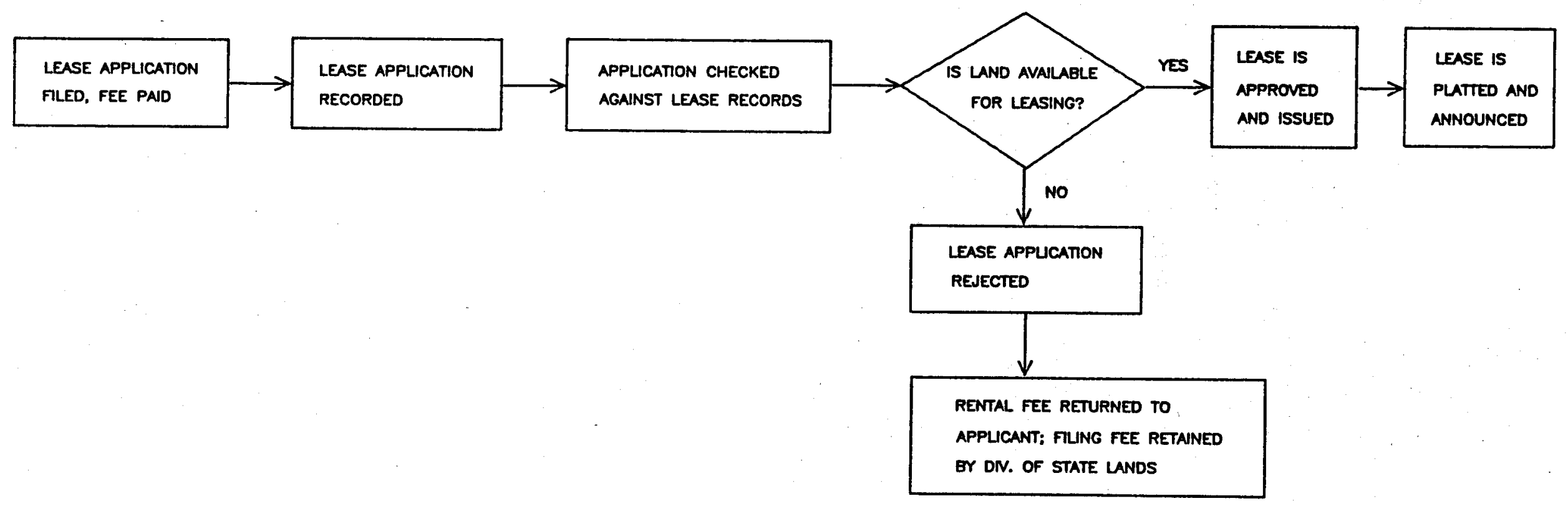

C. . 
STATE LEASES - SIMULTANEOUS FILING

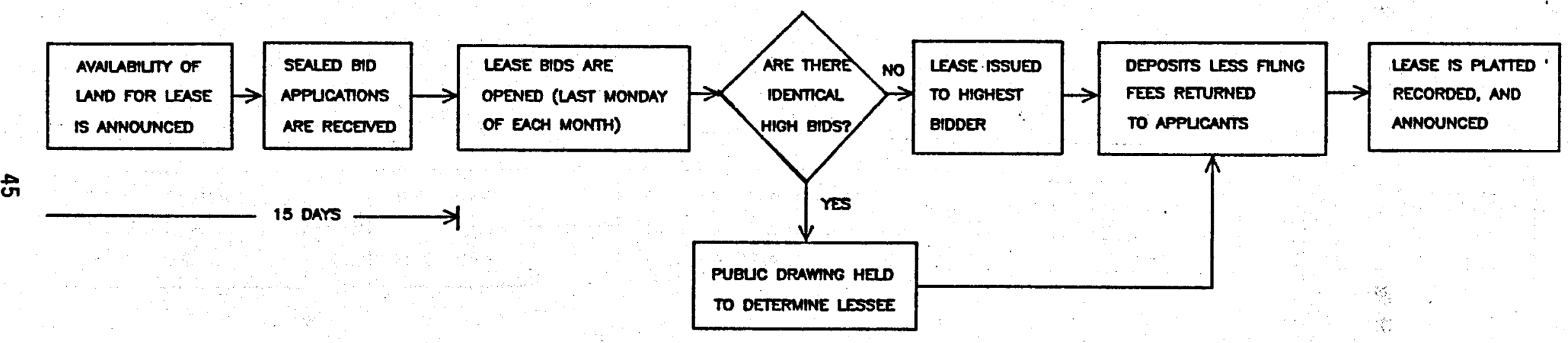


STATE ENVIRONMENTAL HEALTH PERMITS

BUREAU OF WATER POLLUTON CONTROL

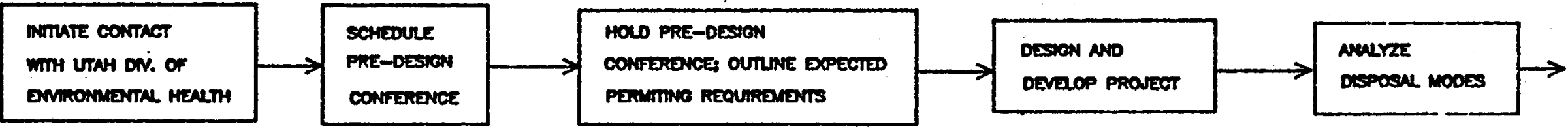




\section{BUREAU OF WATER POLLUTION CONTROL (CONTINUED)}

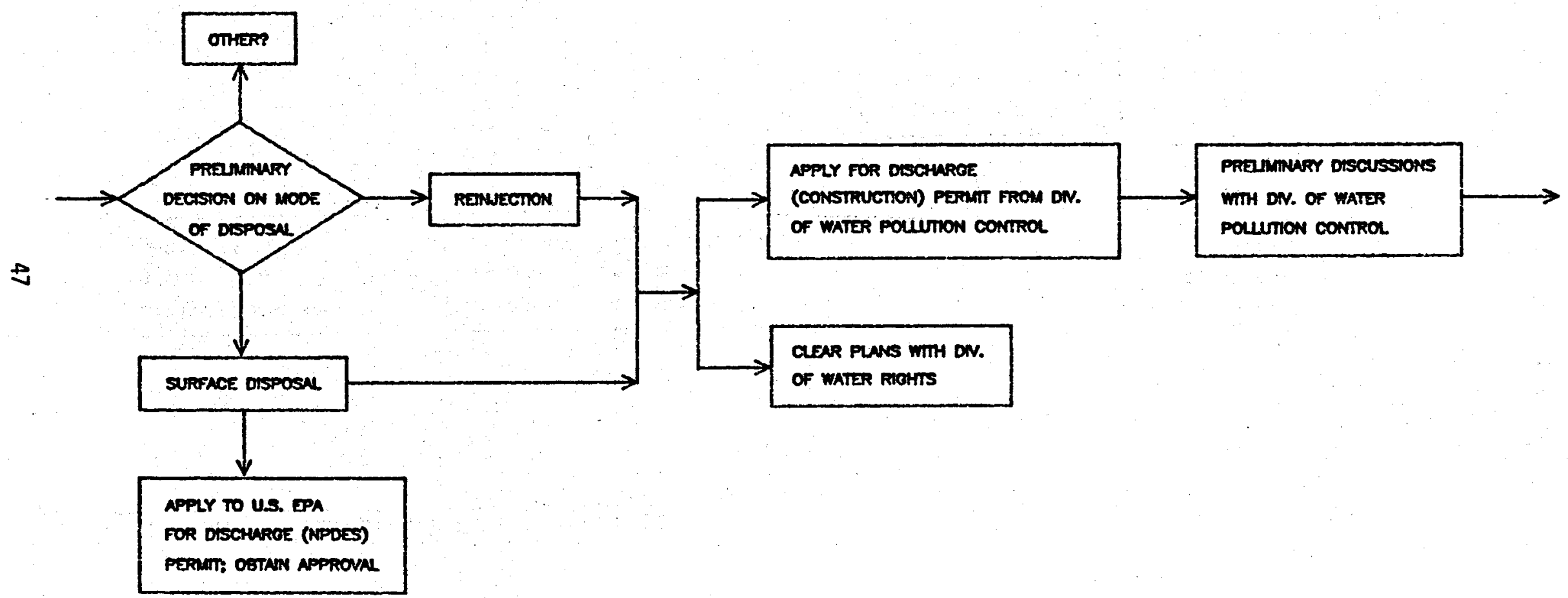


BUREAU OF WATER POLLUTION CONTROL (CONTINUED)

$\stackrel{\infty}{\infty}$

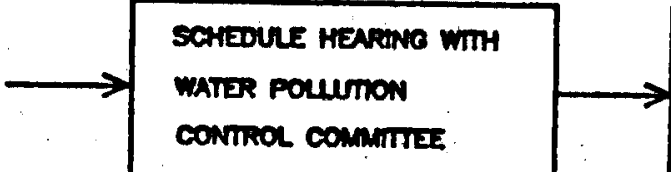

\section{HOL HEARTE WTH WATER}

POUUTON CONIROL COIMUITIEE

(RECURARTY SOHIDULD EACH MONTH)

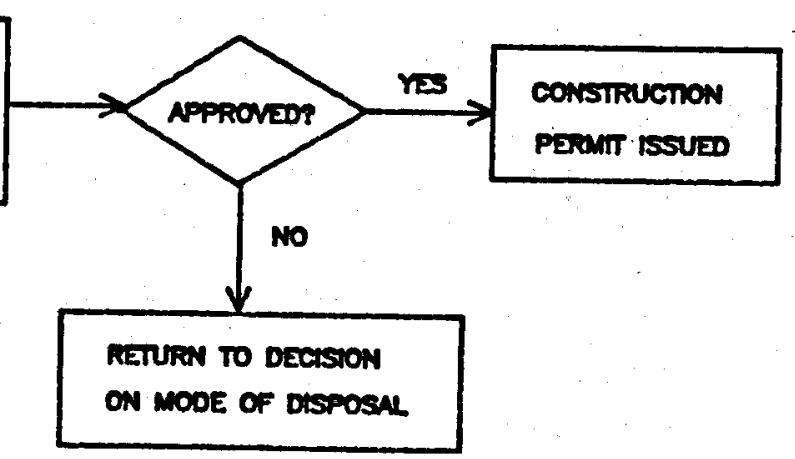

$r$. 
DETAILED PROCEDURE FOR THE GRANTING OF WATER RIGHTS

APPUCATION FIED, FEES PAND; RECORDED. RECEPT ISSUED

$\longrightarrow \sqrt{\begin{array}{l}\text { APPLCATION } \\ \text { MMCRORLMIED AND } \\ \text { PLATIED }\end{array}} \rightarrow \longrightarrow$

PLATIED

APPLCATION
ADVERTSED
(3 WEEKS) $\rightarrow$

(3 WeEks)

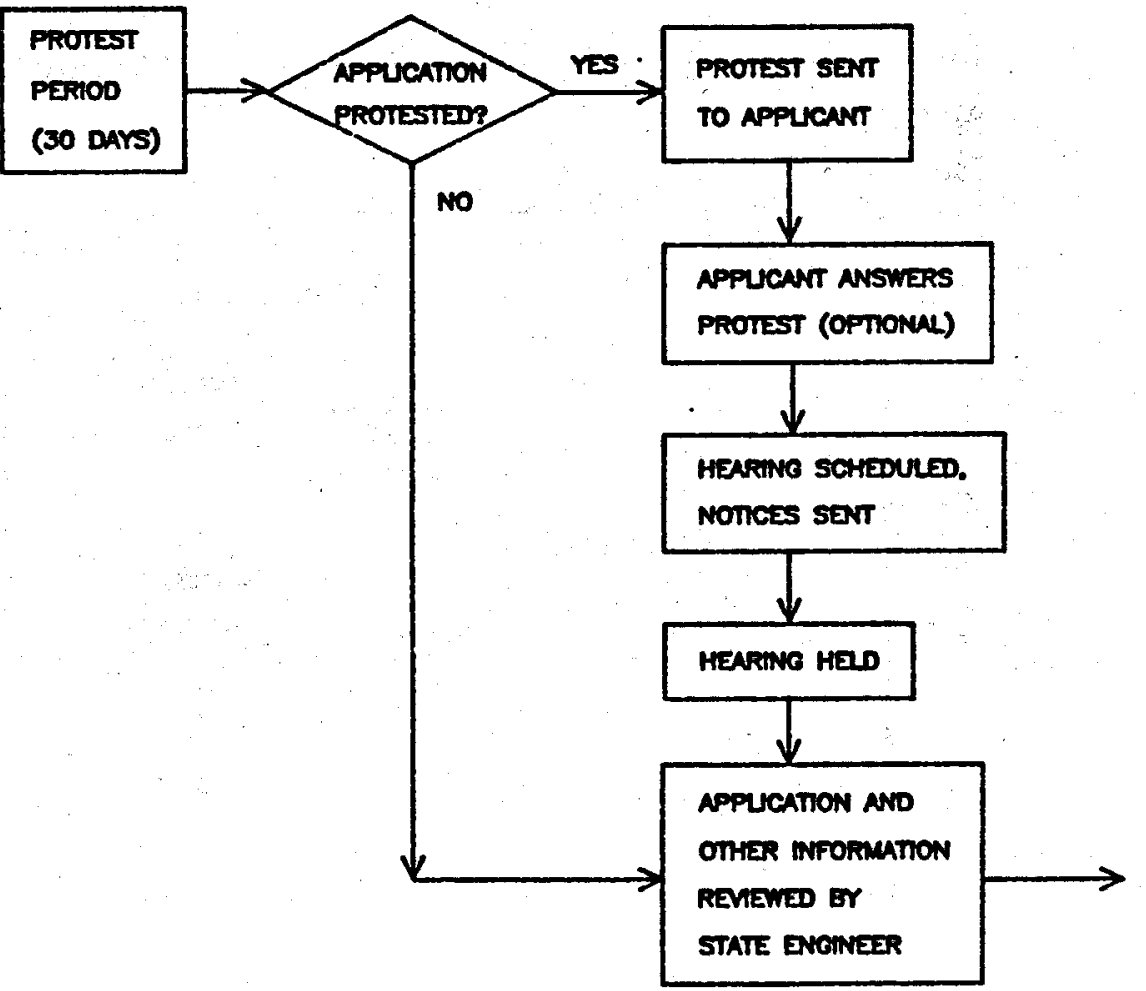

HEAFTNG SCHEDULED,

Monces SEN

HEARMV HED

APPLCATION AMD

REMEWED EY 


\section{WATER RIGHTS (CONTINUED)}

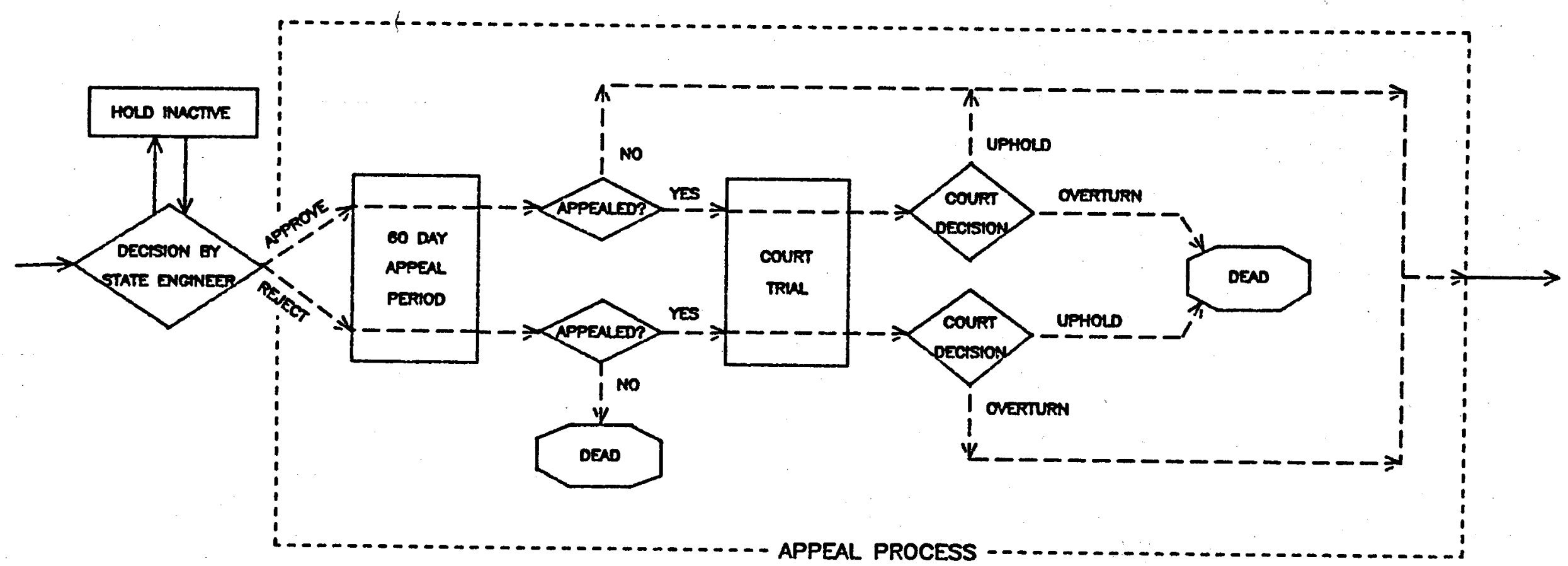




\section{WATER RIGHTS (CONTINUED)}

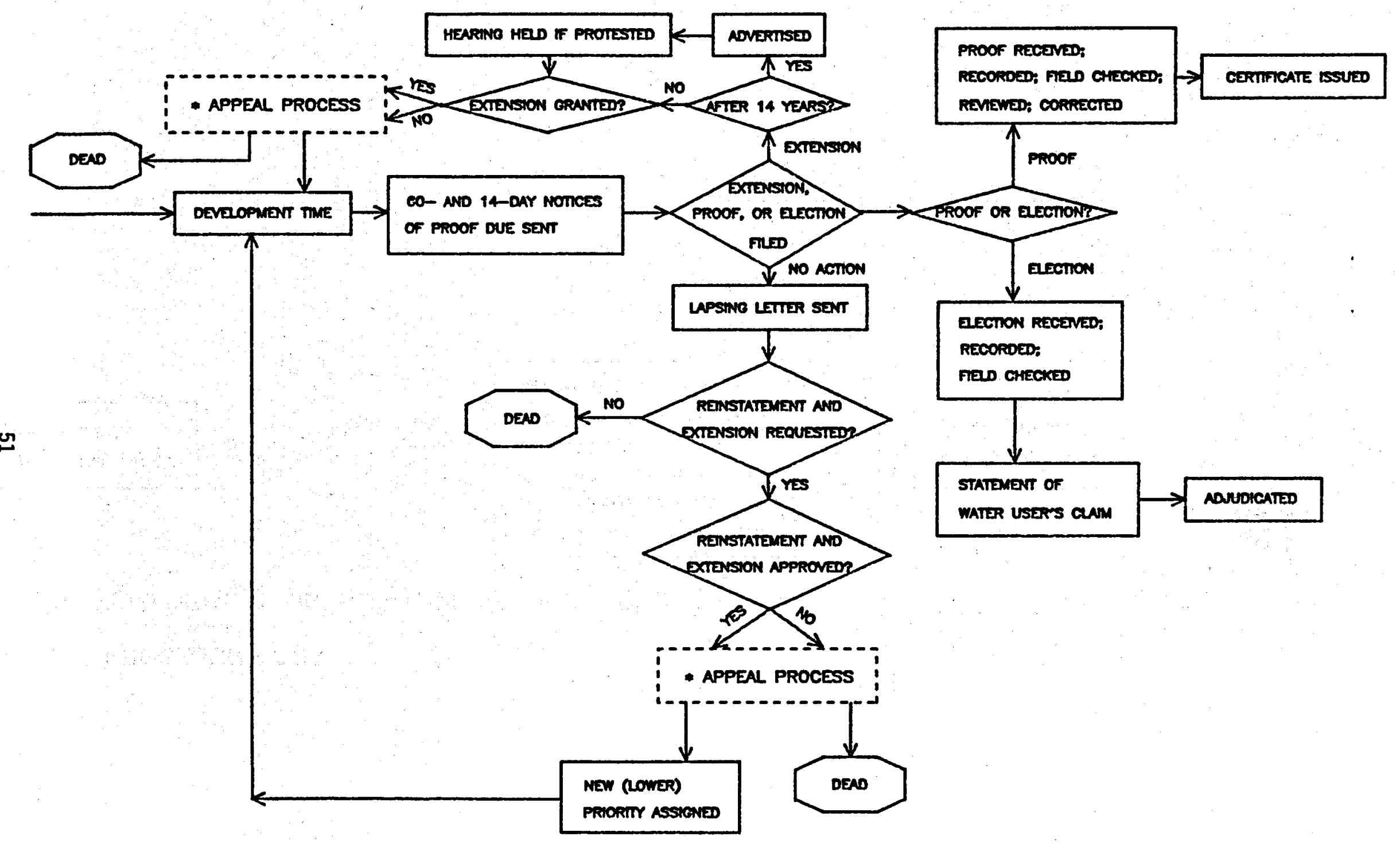


TYPICAL PROCEDURE FOR

MAJOR DEVELOPMENT ON BLM LAND (SIMPLIFIED)

N

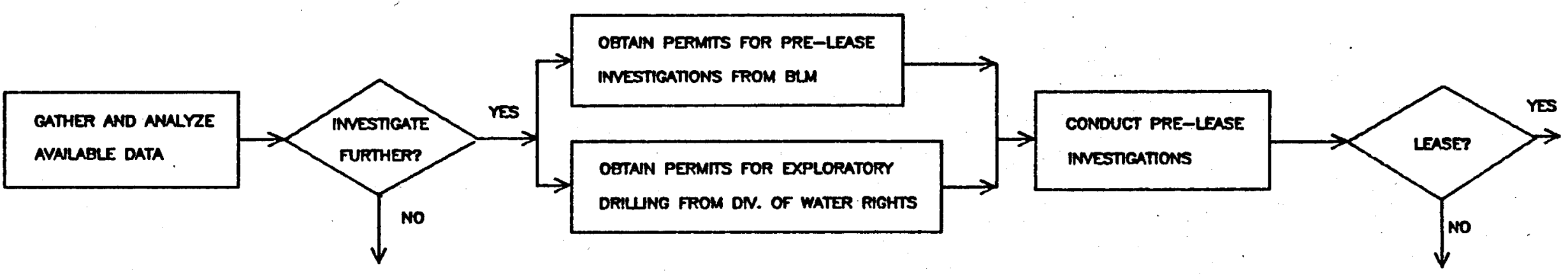




\section{MANOR DEVELOPMENT ON BLM LANDS (CONTINUED)}

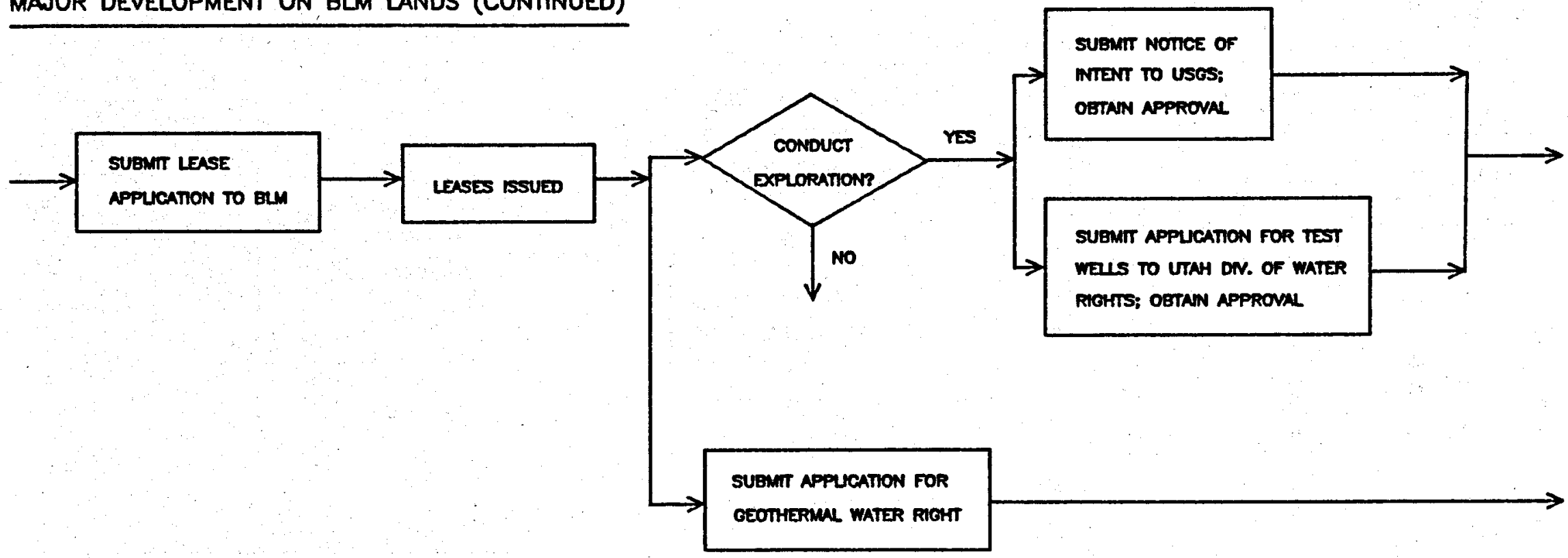




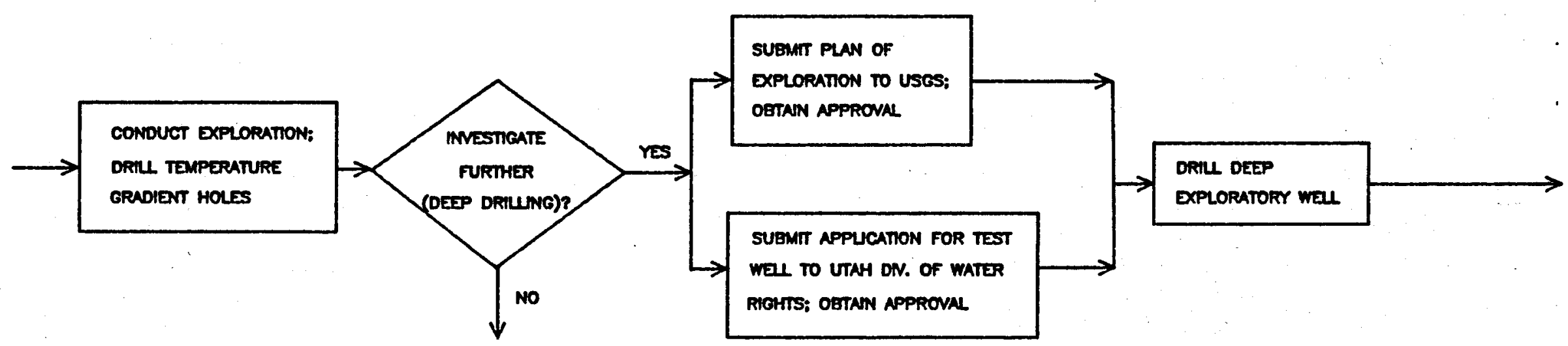




\section{MAJOR DEVELOPMENT ON BLM LANDS (CONTINUED)}

জ

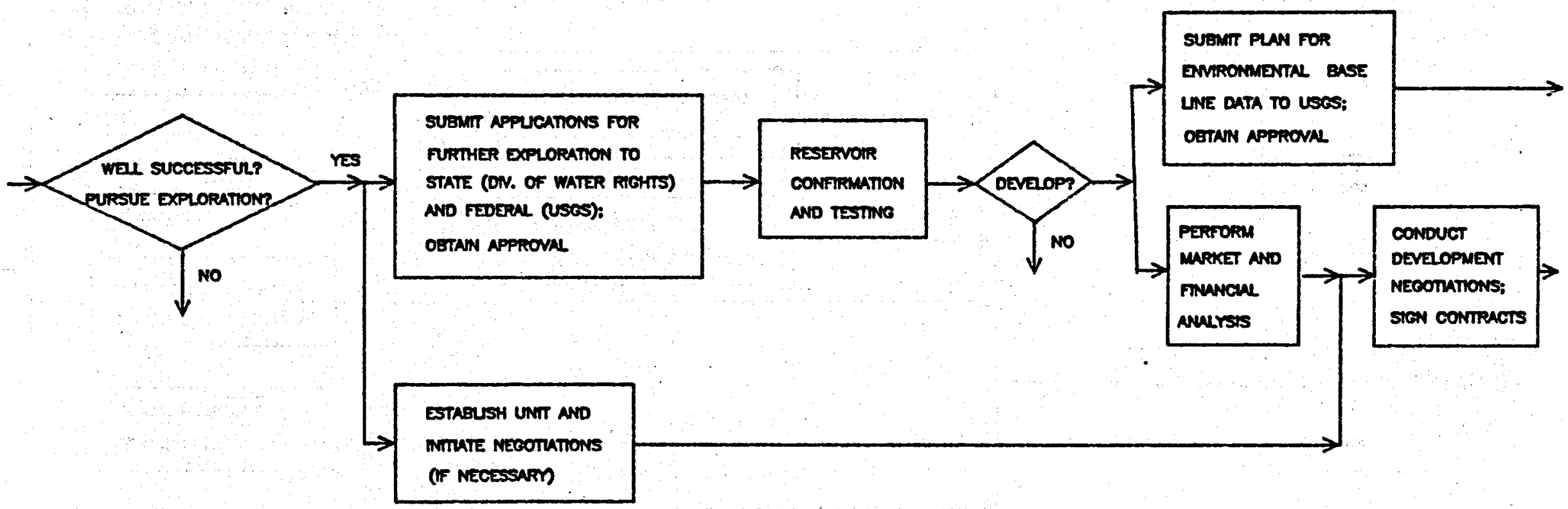

(GEOTHERTNL WATER PAOH) 
MAJOR DEVELOPMENT ON BLM LANDS (CONTINUED)

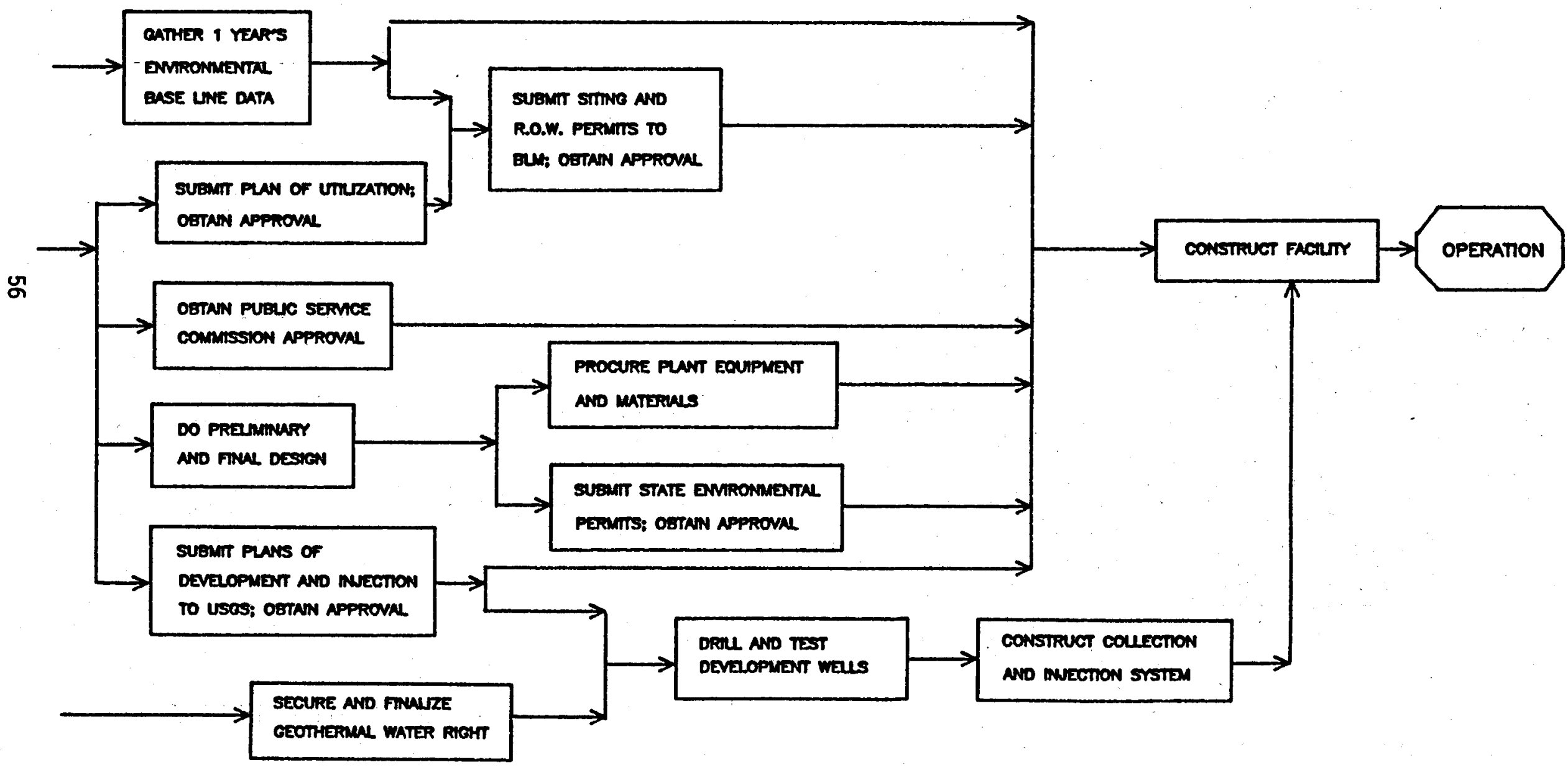




\section{TYPICAL RESOURCE ASSESSMENT PROGRAM}

\section{LOW OR MODERATE TEMPERATURE RESOURCE $\left(<120^{\circ} \mathrm{C}\right)$}

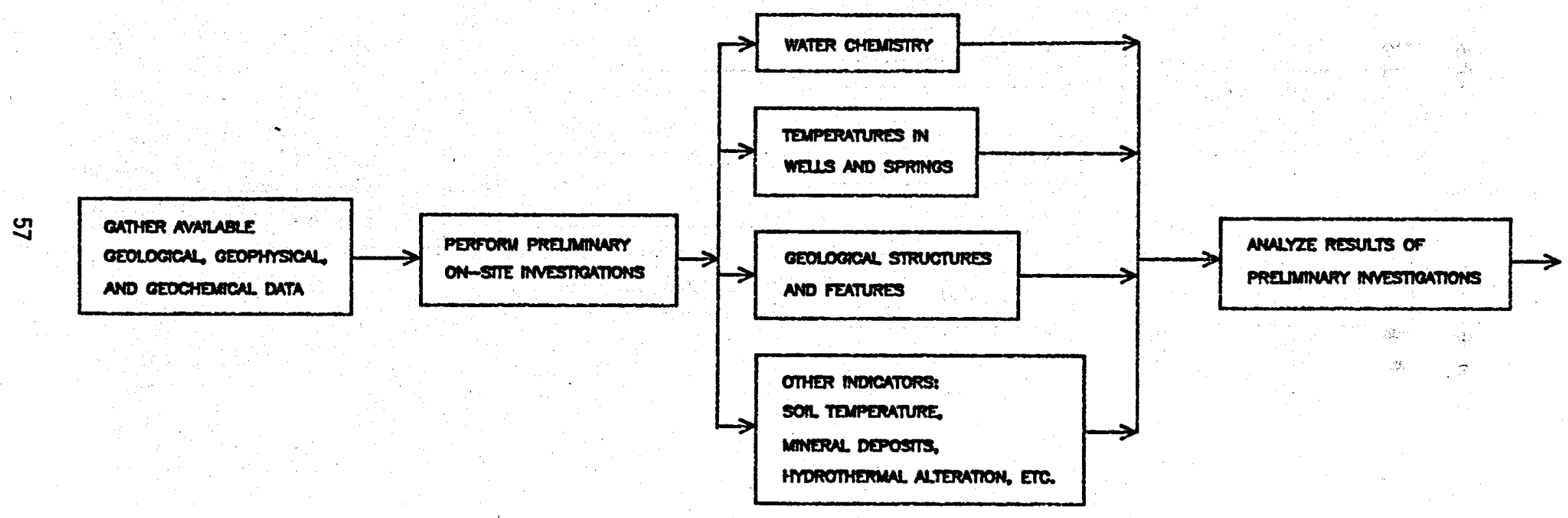


TYPICAL RESOURCE ASSESSMENT PROGRAM (CONTINUED)

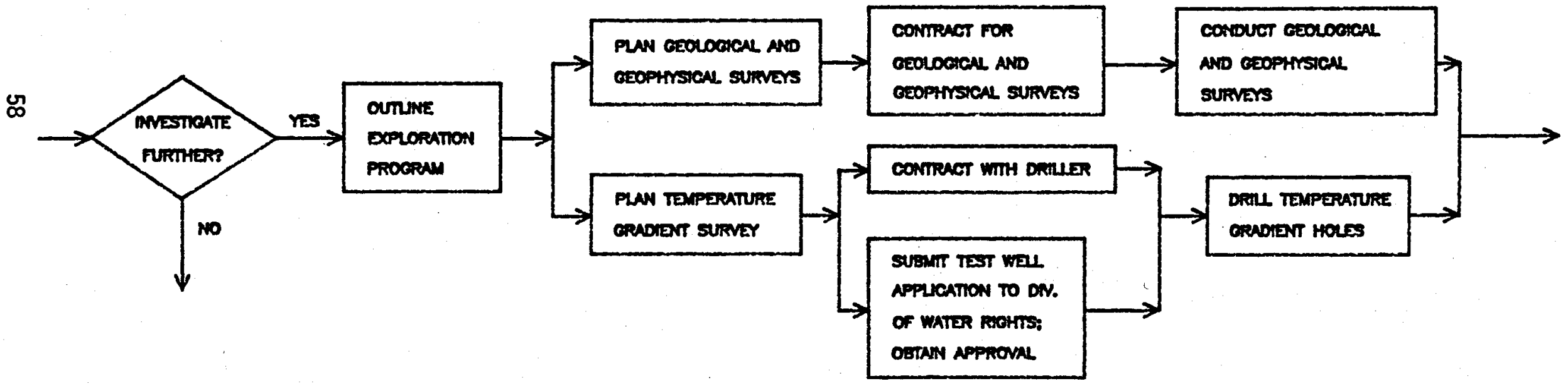


TYPICAL RESOURCE ASSESSMENT PROGRAM (CONTINUED)

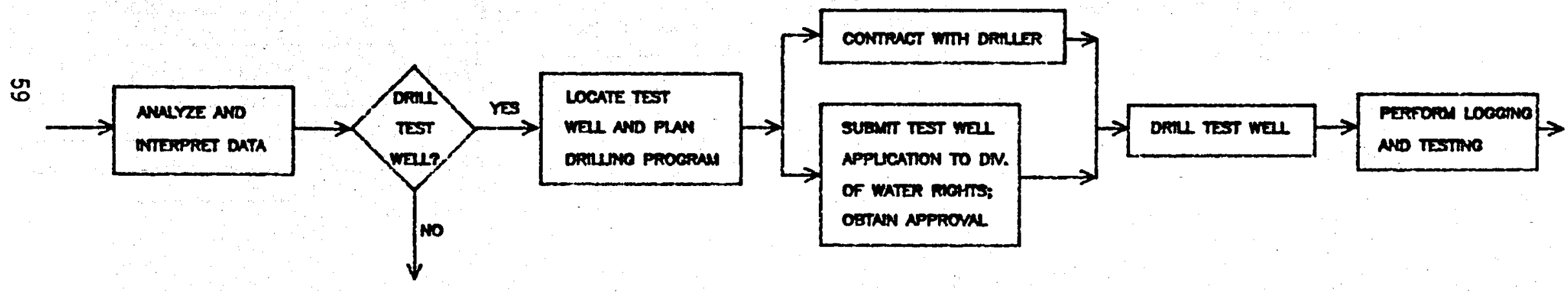




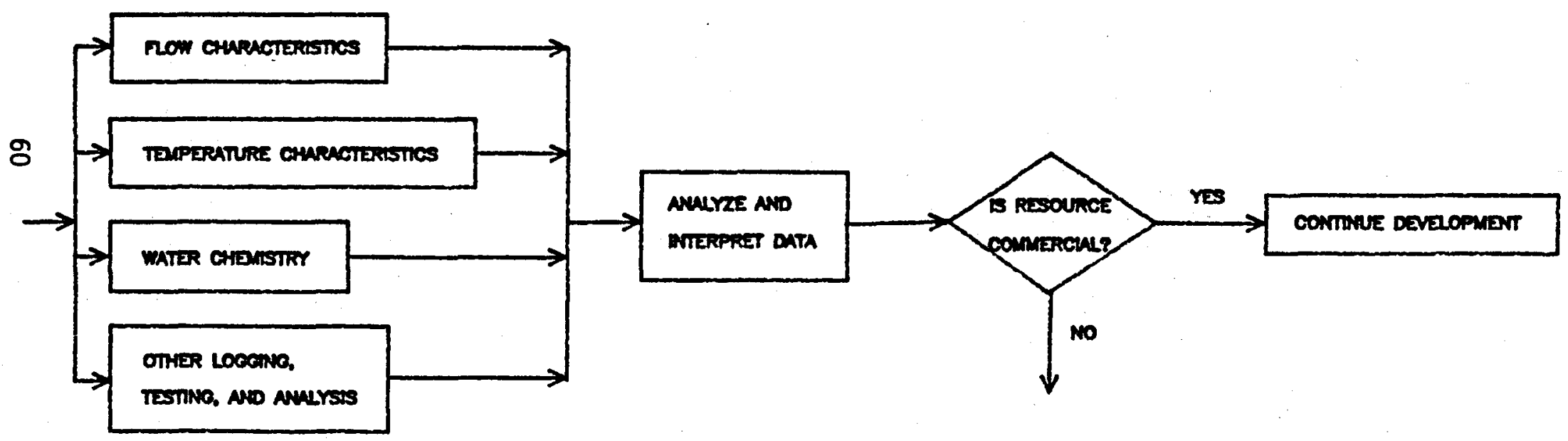

C. 
TYPICAL PROCEDURE FOR DEVELOPMENT OF

LOW OR MODERATE TEMPERATURE RESOURCES $\left(<120^{\circ} \mathrm{C}\right)$

GATHER PREUMINARY INFORMATION

SECURE RIGHTS

TO RESOURCE

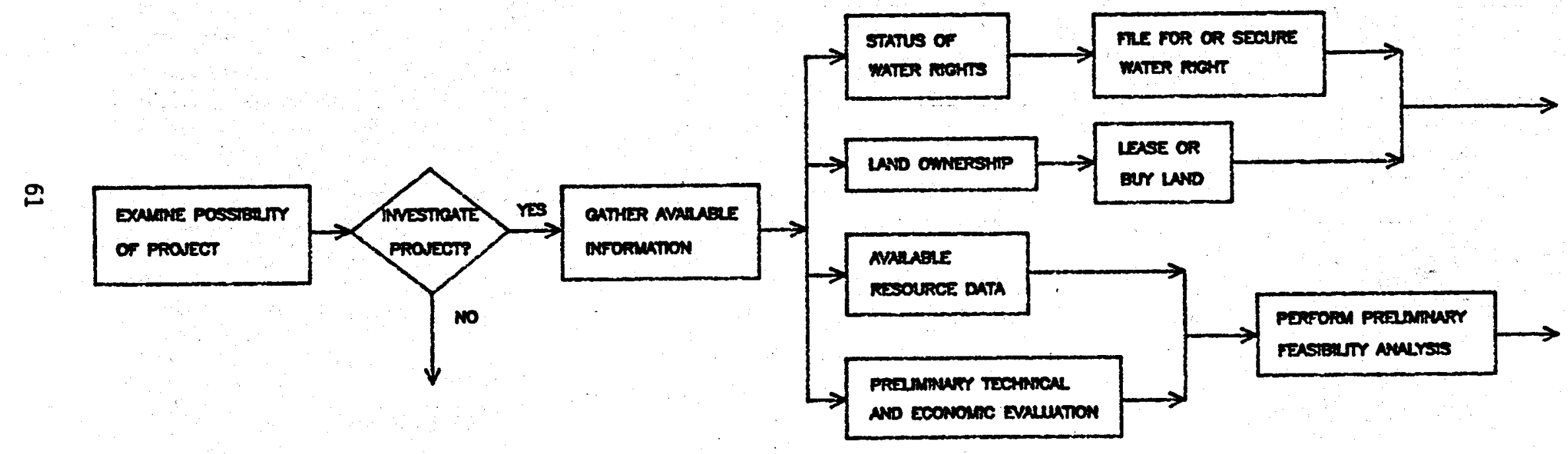




\section{DEVELOPMENT OF MODERATE TEMPERATURE RESOURCES (CONTINUED)}

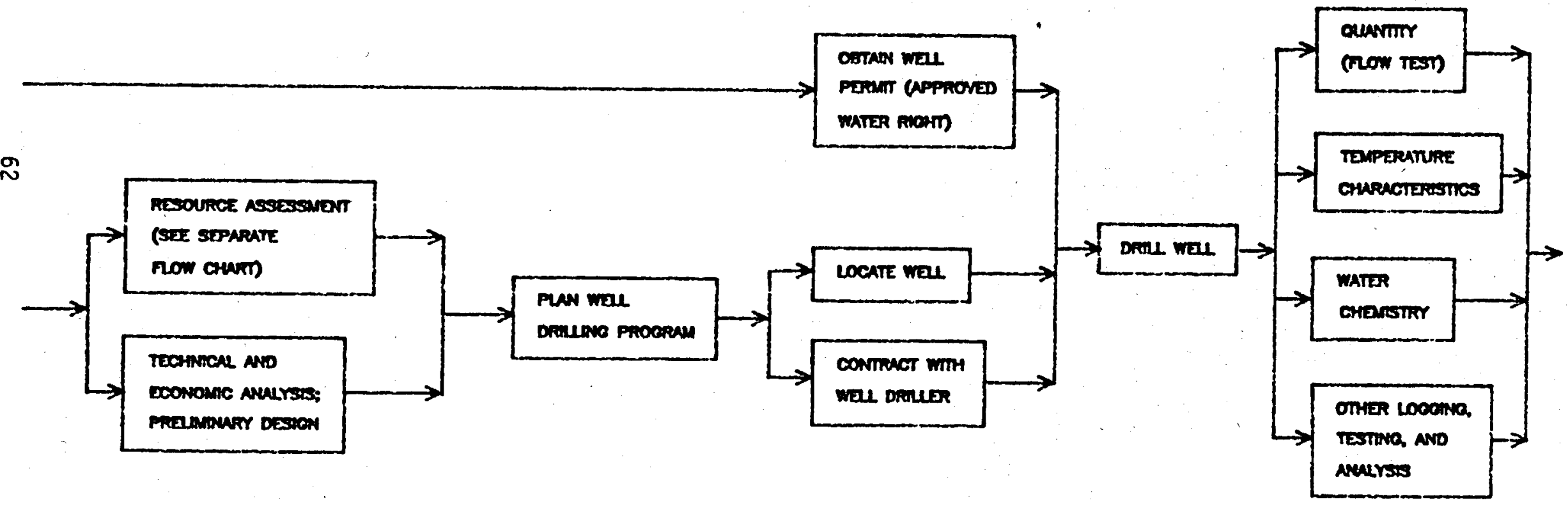




\section{DEVELOPMENT OF MODERATE TEMPERATURE RESOURCES (CONTINUED)}

FINAL DESIGN EMMRONMENTAL PERMITS

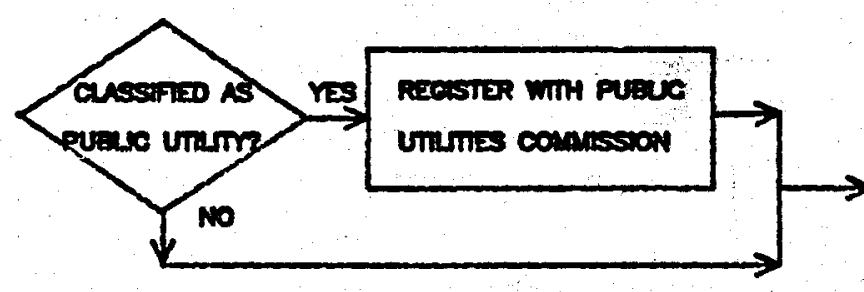

\&

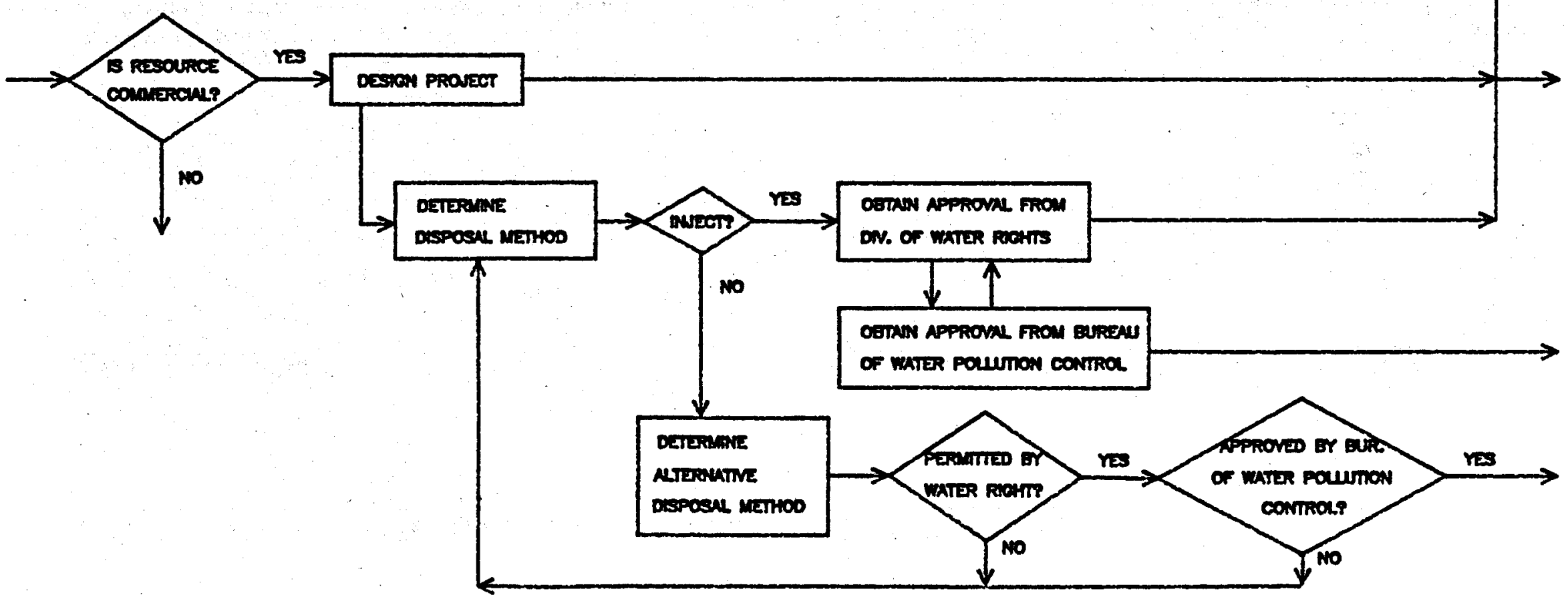


DEVELOPMENT OF MODERATE TEMPERATURE RESOURCES (CONTINUED)

CONSTRUCTION PERMITS

CONSTRUCTON

OPERATION

$\$$

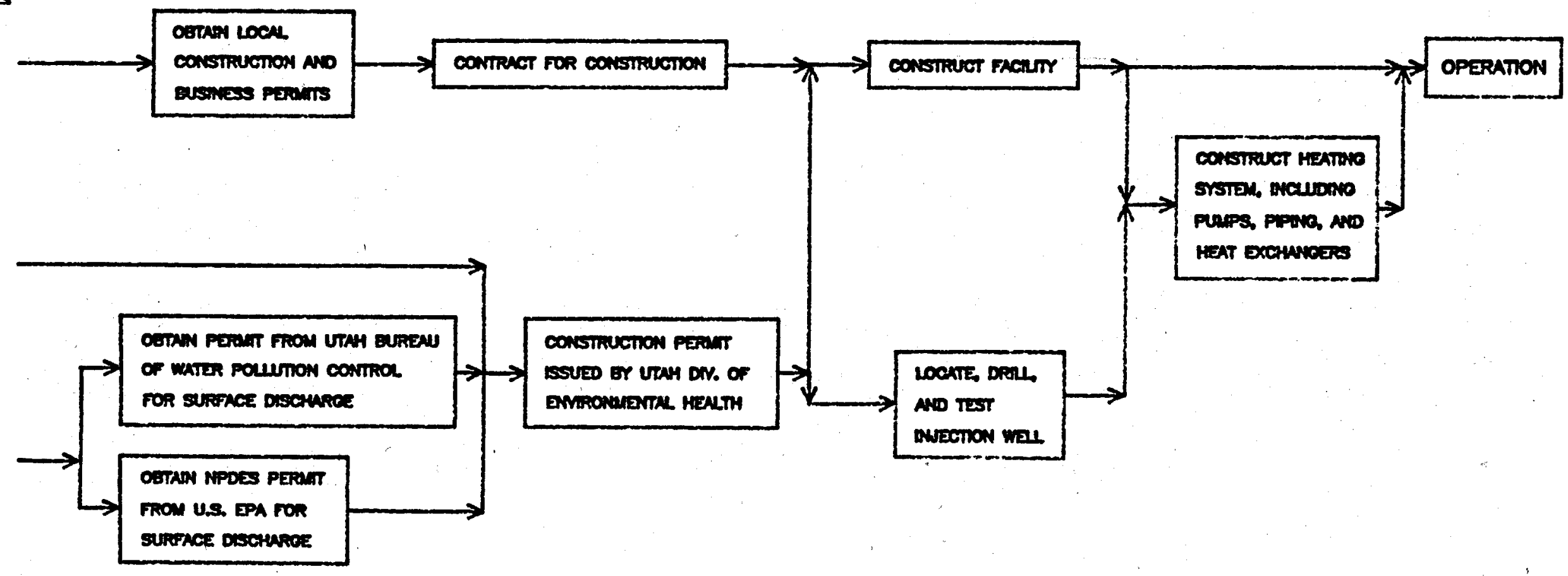

ri. 
HEAT PUMP APPLICATIONS OF GROUNDWATER USE

In recent years, attention has been given to the use of groundwater heat pumps for space heating and cooling of buildings ranging in size from individual homes to multiple-structure commercial and office complexes. Groundwater heat pumps can offer significant savings over conventional energy systems under certain circumstances, but each case should be examined individually to detemine whether an economic advantage exists.

Most heat pumps which use groundwater operate by circulating the water from a well into a heat exchanger where heat is transferred out of the water into a cool, liquid refrigerant, causing it to vaporize. The gaseous refrigerant is then compressed, raising the temperature. The refrigerant, now a hot gas, passes through a fan coil where heat is transferred out of it and circulated through the house. As the heat is transferred out of the refrigerant, it is condensed to a liquid. It passes through an expansion device, which lowers the pressure, and, accordingly, the temperature. The refrigerant is now a cold liquid ready to pass through the heat exchanger, pick up heat from the groundwater, and start the cycle again. After the groundwater has passed through the heat exchanger and has given up heat, it is discharged, usually to an injection well.

In accordance with Utah Law, an approved water right is required for all uses of water within the state, including non-consumptive uses such as heat pumps or low-head hydropower. Application for a water right for these purposes is made through the standard water right procedure, and should specify the use, amount, location, the consumptive or non-consumptive nature of the proposed use, method of disposal, and other relevant information. If the heat pump is to be connected to an existing well and used under an existing water right, a change application may be filed to include the heat pump in the right. In any case, an approved application stating the specific use must be on file with the Division of Water Rights before the system is 
put into operation.

Disposal of spent groundwater by reinjection will be required in most cases in order to protect the groundwater resource and to utilize it most efficiently. In some areas of Utah, the groundwater is already seriously depleted; in those areas, no new water rights for consumptive use will be approved, and new applications for heat pump or geothermal use will not be approved unless the plans include disposal by reinjection. Reinjection is also required in urban areas of the state where population is dense and a high demand is placed on the groundwater supply. In some areas, the groundwater supply may be sufficient that surface disposal is allowable; in such cases, the prospective user should still check with the appropriate agencies, particularly the Division of Environmental Health, Bureau of Water Pollution Control, about the potential for surface water contamination (in most cases this will not be a problem because the water is taken from shallow aquifers).

A two-well system is usually used for reinjection; this allows the wells to be alternated for heating and cooling, and this kind of heat storage system can increase the efficiency of the heat pump system. A single well production/injection system has been proposed, but is still unproven.

An approved water right or test well permit is necessary before a production or injection well may be drilled, and the driller must have a current drilling license from the state. A complete well log must be submitted, and other general regulations for water well drilling must be followed.

At the present time, there are no state or federal tax incentives for heat pump use. 
Hydrothermal Resources

Clement, M.D., and Chapman, D.S., 1981, Heat Flow and Geothermal Assessment of the Escalante Desert, Southwestern Utah, with Emphasis on the Newcastle KGRA: University of Utah Department of Geology and Geophysics.

Glenn, W.E., et al, 1980, Geothermal Exploration Program - Hill Air Force Base, Weber County, Utah: University of Utah Research Institute, Earth Science Laboratory, ESL-34.

Goode, H.D., 1978, Thermal Waters of Utah, Utah Geological and Mineral Survey Topical Report.

McKinney, D.B., Annotated Bibliography of the Geology of the Roosevelt Hot Springs Known Geothermal Resource Area and the Adjacent Mineral Mountains, March 1978: University of Utah Research Institute, Earth Science Laboratory.

Muffler, L.J.P., Editor, Assessment of Geothermal Resources of the United States - 1978: U.S. Geological Society Circular 790.

Mundorf, J.C., 1970, Major Thermal Springs of Utah: Utah Geological and Mineral Survey, Water Resources Bulletin 13.

Kohler, J.F., 1979, Geology, Characteristics, and Resource Potential of the Low-Temperature Geothermal System near Midway, Wasatch County, Utah: Utah Geological and Mineral Survey Report of Investigation No. 142.

Murphy, P.J., and Gwynn, J.W., 1979, Geothermal Investigations at Crystar Hot Springs, Salt Lake County, Utah: Utah Geological and Mineral Survey Report of Investigation No. 139.

Murphy, P.J., and Gwynn, J.W., 1979, Geothermal Investigations of the Warm Springs Fault Geothermal System, Salt Lake County, Utah: Utah Geological and Mineral Survey Report of Investigations No. 140.

Murphy, P.J., and Gwynn, J.W., 1979, Geothermal Investigations at Selected Thermal Systems of the Northern Wasatch Front, Weber and Box Elder Counties, Utah: Utah Geological and Mineral, Survey Report of Investigation No. 141.

Utah Geological and Mineral Survey, Geothermal Resources of Utah, 1980: Map prepared by National Oceanic and Atmospheric Administration for the U.S. Department of Energy.

White, D.E., and Williams, D.L., Editors, Assessment of Geothermal Resources of the United States - 1975: U.S. Geological Survey Circular 726. 
Anderson, D.N., and Lund, J.L., 1979, Direct Utilization of Geothermal Energy: A Technical Handbook: Geothermal Resources Council and Oregon Institute of Technology, Geothermal Resources Council Special Report No. 7.

EG\&G Idaho, Inc., 1980, Rules of Thumb for Geothermal Direct Applications: EG\&G Idaho, Inc., Idaho Falls, Idaho.

Engen, I.A., 1978, Residential Space Heating Cost: Geothermal vs. Conventional Systems: EG\&G Idaho, Inc.

Lienau, P.J., and Lund, J.W., 1974, Multipurpose Use of Geothermal Energy: Proceedings of the International Conference on Geothermal Energy for Industrial, Agricultural, and Commercial - Residential Uses, Geo-Heat Utilization Center, Oregon Institute of Technology, Klamath Falls, Oregon.

Longyear, A.B., Brink, W.R., Fisher, L.A., Matherson, R.H., Neilson, J.A., and Sanyal, S.K., 1979, Mountain Home Geothermal Project, Geothermal Energy Appi ications in an Integrated Livestock Meat and Feed Production Facility at Mountain Home, Idaho: Energetics Marketing \& Management Associates, Ltd..

Swink, D.G., and Schultz, R.J., 1976, Conceptual Study for Total Utilization of an Intermediate Temperature Geothermal Resource: Aerojet Nuclear Company.

Heat Pumps

Clyde, C.G., Vende11, E.W., and Hagen, K.D., 1979, Groundwater Heat Pump An Efficient Way to Heat and Cool Your Home: Utah Water Research Laboratory, Utah State University, Logan, Utah.

Clyde, C.G., Vendell, E.W., amd Hagen, K.D., 1979, Groundwater Heat Pump Equipment Selection Procedures for Architects, Designers, \& Contractors: Utah Water Research Laboratory, Utah State University, Logan, Utah.

National Water Well Association, Ground Water Heat Pumps: National Water Well Association.

Schaetzle, W.J., and Brett, C.E., 1979, Heat Pump Centered Integrated Community Energy Systems: Bureau of Engineering Research and Natural Resources Center, the University of Alabama, and Argonne $\mathrm{Na}-$ tional Laboratory.

Institutional and Legal

Green, S., and Wagstaff, L.W., 1979, Time Phased Project Plan for Roosevelt Hot Springs Geothermal Area: Utah Division of Water Rights. 
King, 'D., Nimmons, J.T., and Hanemann, W.M., 1980, The Role of Gas and Electric Utilities in Direct Applications of Geothermal Resources: The Earl Warren Legal Institute, University of California, Berkeley, California.

Nimmons, J.T., Ross, L., and Metzger, J., 1979, Overview of State Public Utility Regulation Impact on Geothermal Direct Heat Applications:

The Earl Warren Legal Institute, University of California, Berkeley, California.

Nimmons, J.T., Kotz, S., and Metzger, J., 1979, State-by-State Analysis of Public Utility Laws Affecting Geothermal Direct Heat Applications: The Earl Warren Legal Institute, University of California, Berkeley, California.

\section{Electrical Production}

Kestin, J., Editor-in-chief, 1980, Sourcebook on the Production of Electricity from Geothermal Energy: U.S. Department of Energy.

\section{Other Sources of Information}

University of Utah Reseanch Institute, Earth Science Laboratory,

Salt Cake City, Utah

- Geological and geophysical reports

- Case study reports

- Drill cutting samples

University of Utah, Department of Geology and Geophysics

- Geological and geophysical reports

EG\&G Idaho, Inc., Idaho Falls, Idaho

- Technical and economic reports.

Geothermal Resource Council

- Monthly bulletin

- Proceedings of annual meetings

- Special reports

- Symposia and workshops

New Mexico Energy Institute, New Mexico State University, Las Cruces, New Mexico

- Data base compilation

- Computer analysis of direct use and electrical projects

Geo-Heat Utilization Center, Oregon Institute of Technology, Klamath Falls, Oregon

- Direct use technology and economics

Utah Division of Water Rights, Geothermal Commercialization Program, Salt Lake City, Utah

- Progress reports

- Technical and economic analysis 
Utah Geological and Mineral Survey, Salt Lake City, Utah

- General Geological reports and maps

- Data on Hydrothermal resources in Utah

Geothermal Publications (Partial List)

Geothermal Energy - monthly magazine

The Geyser - newsletter

Petroleum Information - Geothermal newsletter and drilling updates

Geo-Heat Utilization Center - quarterly bulletin

National Water Well Association - Ground Water Heat Pump Journal

Utah Water/Geothermal Report - newsletter 
APPENDIX A

GEOTHERMAL RESOURCE CONSERVATION ACT

1981

GENERAL SESSION

Enrolled Copy,

s. B. No. 43

By Fred w. Finlinson

Glade M. Sowards

AN ACT RELATING TO THE DEVELOPMENT OF GEOTHERMAL RESOURCES IN THE STATE; DECLARING THE PUBLIC INTEREST IN THIS DEVELOPMENT AND ASSIGNING REGULATORY AUTHORITY REGARDING THIS TO TEE DIVISION OF WATER RIGETS; DEFINING THE RESOURCE AND ITS RELATIONSHIP TO WATER; PROVIDING FOR THE PROTECTION OF CORRELATIVE RIGHTS AND THE PREVENTION OF WASTE; AUTHORIZING AND ESTABLISHING PROCEDURES FOR UNITIZING OF GEOTHERMAL AREAS; AND PROVIDING FOR PROCEDURES TO GOVERN REGULATION BY IHIS DIVISION:

THIS ACT ENACTS THE UTAH GEOTHERMAL RESOURCE CONSERVATION ACT BY ENACTING SECTIONS 73-21-1 THROUGA 73-21-10, UTAF CODE ANNOTATED 1953; AND REPEALS SECTION 73-1-20, UTAH CODE ANNOTATED 1953, AS ENACTED BY CHAPTER 189, LAWS OF UTAF 1973.

Be it enacted by the Legislature of the state of Utah:

Section 1. Section 73-21-1, Utah code Annotated 1953, is enacted to read:

73-21-1. This chapter shall be known and may be cited as the "Utah Geothermal Resource Conservation Act."

Section 2. Section 73-21-2, Utah Code Annotated 1953, is enacted to read:

73-21-2. It is declared to be in the public interest to foster, encourage, and promote the discovery, development, production, utilization, and disposal of geothermal resources in the state of Utah in such manner as will prevent waste, protect correlative rights, and safeguard the natural 
S. B. No. 43

environment and the public welfare; to authorize, encourage, and provide for the development and operation of geothermal resource properties in such manner that the maximum ultimate economic recovery of geothermal resources may be obtained through, among other things, agreements for cooperative development, production, injection, and pressure maintenance operations.

Section 3. Section 73-21-3, Utah Code Annotated 1953, is enacted to read:

73-21-3. As used in this chapter:

(1) "Correlative rights" mean the rights of each geothermal owner in a geothermal area to produce without waste his just and equitable share of the geothermal resource underlying the geothermal area.

(2) "Division" means the division of water rights, department of natural resources.

(3) "Geothermal area" means the general land area which is underlain or reasonably appears to be underlain by geothermal resources.

(4) "Geothermal fluid" means water and steam at temperatures greater than 120 degrees centigrade naturally present in a geothermal system.

(5) "Geothermal resource" means: (a) the natural heat of the earth at temperatures greater than 120 degrees centigrade; and (b) the energy, in whatever form, including pressure, present in, resulting from, created by, or which may be extracted from that natural heat, directly or through a material medium. Geothermal resource does not include geothermal fluids.

(6) "Geothermal system" means any strata, pool, reservoir, or other geologic formation coritaining geothermal resources. 
S. B. No. 43

(7) "Material medium" means geothermal fluids, or water and other substances artificially introduced into a geothermal system to serve as a heat transfer medium.

(8) "Operator" means any person drilling, maintaining, operating, producing, or in control of any well.

(9) "Owner" means a person who has the right to drill into, produce, and make use of the geothermal resource.

(10) "Person" means any individual, business entity (corporate or otherwise), or political subdivision of this or any other state.

(11) "Waste" means any inefficient, excessive, or improper production, use, or dissipation of geothermal resources, Wasteful practices include, but are not 1 imited to: (a) transporting or storage methods that cause or tend to cause unnecessary surface loss of, geothermal resources; or (b) locating, spacing, constructing, equipping, operating, producing, or venting of any well in a manner that results or tends to result in unnecessary surface 1058 or in reducing the ultimate economic recovery of geothermal resources.

(12) "Well" means any well drilled, converted, or reactivated for the discovery, testing, production, or subsurface injection of geothermal resources.

section 4. Section 73-21-4, Utah Code Annotated 1953, is enacted to read:

73-21-4. (1) ownership of a geothermal resource derives Erom an interest in 1 and and not from an appropriative right to geothermal fluids.

(2) This chapter shall apply to all lands in the state of Utah, Including federal and Indian lands to the extent allowed by law. When these lands are committed to a unit agreement involving lands subject to federal or Indian jurisdiction, the division may, with respect to the unit agreement, deem this chapter complied with if the unit operations are regulated by 
S. B. No. 43

the United states and the division finds that conservation of geothermal resources and prevention of waste are accomplished under the unit agreement.

Section 5. Section 73-21-5, Utah Code Annotated 1953, is enacted to read:

73-21-5. (1) The division is granted jurisdiction and authority over all persons and property, public and private, necessary to enforce the provisions of this chapter and shall have the power and authority to adopt and enforce rules, regulations, and orders and do whatever may reasonably be necessary to carry out this chapter.

(2) Any affected person may apply for a hearing before the division, or the division may initiate proceedings upon any question relating to the administration of this chapter, and jurisdiction is conferred upon the division to hear and determine the same and enter its rule, regulation, or order with respect to the matter.

(3) The division shall have the power to summon witnesses, to administer oaths, and to require the production of records, books, and documents for examination at any hearing or investigation conducted by it.

(4) In case of failure or refusal on the part of any person to comply with a subpoena issued by the division, or in case of refusal of any witness to testify as to any matter regarding which he may be interrogated, any district court in the state, upon the application of the division, may issue an order compelling the person to comply with the subpoena and to attend before the division and produce any records, books, and documents covered by the subpoena or to give testimony or both. The court shall have the power to punish for contempt as in the case of disobedience to a like subpoene issued by the court, or for refusal to testify in the court. 
S. B. No. 43

(5) Whenever it appears that any person is violating or threatening to violate any provision of this chapter or any rule, regulation, or order made under this chapter, the division may bring suit in the name of the state against that person in the district court in the county of that person's residence, in the county of the residence of any defendant if there be more than one defendant, or in the county where the violation is alleged to have occurred, to restrain that person from continuing the violation or from carrying out the threat of violation. In the suit the court may grant injunctions:

(6) Nothing in this chapter, no suit by or against the division, and no violation charged or asserted against any person under this chapter, or any rule, regulation, or order issued under it, shall impair or abridge or delay any cause of action for damages which any person may have or assert against any person violating this chapter, or any rule, regulation, or order issued under it. Any person so damaged by the violation may sue for and recover such damages as he otherwise may be entitled to receive.

Section 6. Section 73-21-6, Utah Code Annotated 1953, is enacted to read:

73-21-6. (1) The division shall have authority to require:

(a) Identification of the location and ownership of all wells and producing geothermal leases.

(b) Filing with the division of a notice of intent to drill, redrill, deepen, permanently alter the casing of, or abandon any well. Approval of the notice of intent must be obtained from the division prior to commencement of operations.

(c) Keeping of well logs and filing true and correct copies with the division." These records are public records when filed with the division, unless the owner or operator requests, in writing, that the records be held confidential. 
S. B. No. 43

The period of confidentiality shall be established by the division, not to exceed five years from the date of production or injection for other than testing purposes or five years from the date of abandomment, whichever occurs first, as determined by the division. Well records held confidential by the division are open to inspection by those persons authorized in writing by the owner or operator. Confidential status shall not restrict inspection by state officers charged with regulating well operations or by authorized officials of the Utah state tax commission for purposes of tax assessment.

(d) The spacing, drilling, casing, testing, operating, producing, and abandonment of wells so as to prevent: geothermal resources, water, gases, or other fluids from escaping into strata other than the strata in which they are found (unless in accordance with a subsurface injection program approved by the division); (ii) pollution of surface and groundwater; (iii) premature cooling of any geothermal system by water encroachment or otherwise which tends to reduce the ultimate economic recovery of the geothermal resources; (iv) blowouts, cavings, and seepage; and (v) unreasonable disturbance or injury to neighboring properties, prior water rights, human life, health, and the environment.

(e) The operator to file cash or individual surety bonds with the division for each new well drilled and each abandoned well redrilled. The amount of surety required shall be determined by the division. In lieu of bonds for separate wells, the operator may file a blanket cash or individual surety bond in an amount set by the division to cover all the operator's drilling, redrilling, deepening, maintenance, or abandonment activities for wells in the state. Bonds filed with the division shall be executed by the operator, as principal, conditioned on compliance with division regulations in drilling, redrilling, deepening, maintaining, or abandoning 
S. B. No. 43

any well or wells covered by the bond and shall secure the state against all losses, charges, and expenses incurred by it to obtain such compliance by the principal named in the bond.

(f) The geothermal owner or operator to measure geothermal production according to standards set by the division and maintain complete and accurate production records. The records, or certified copies of them, shall be preserved on file by the owner or operator for a period of five years and shall be available for examination by the division at all reasonable times.

(g) Filing with the division any other reasonable reports which it prescibes regarding geothermal operations within the state.

(2) Any bond filed with the division in conformance with this chapter may, with the consent of the division, be terminated and canceled and the surety be relieved of all obligations under it when the well or wells covered by the bond have been properly abandoned or another valid bond has been substituted for it.

(3) The division may enter onto private or public land at any time to inspect any well or geothermal resource development project to determine if the well or project is being constructed, operated, or maintained according to any applicable permits or to determine if the construction, operation, or maintenance of the well or project may involve an unreasonable risk to life, health, property, the environment or subsurface, surface, or atmospheric resources.

Section 7. Section 73-21-7, Utah Code Annotated 1953, is enacted to read:

73-21-7. (1) The division upon its own motion may hold, and upon the application of any affected person shall hold, a hearing to consider the need for cooperative or unit operation of a geothermal area. 
5. B. No. 43

(2) The division shall make an order providing for the cooperative or unit operation of part or all of a geothermal area if the division finds that a developable resource exists and that this operation is reasonably necessary to prevent waste, to protect correlative rights, or to prevent the drilling of unnecessary wells and will not reduce the ultimate economic recovery of geothermal resources.

(3) An.order for cooperative or unit operations shall be upon terms and conditions that are just and reasonable and satisfy the requirements of subsection (2).

(4) An order by the division for unit operations shall prescribe a plan, including:

(a) A description of the geothermal area to be so operated, termed the unit area.

(b) A statement of the nature of the operations contemplated, the time they will commence, and the manner and circumstances under which unit operations shall terminate.

(c) An allocation to the separately-owned tracts in the unit area of the geothermal resources produced and of the costs incurred in unit operations. The allocations shall be in accord with the agreement, if any, of the affected parties. If there is no such agreement, the division shall determine the allocations from evidence introduced at a hearing before the division. Production shall be allocated in proportion to the relative value that each tract bears to the value of all tracts in the unit area. The acreage of each tract in proportion to the total unit acreage shall be the measure of relative value, unless the division finds after public hearing that another method is likely to result in a more equitable allocation and protection of correlative rights. Resource temperature, pressure, fluid quality, geological conditions, distance to place of use, and productivity are among the factors that may be considered in evaluating other methods. The method for 
5. B. No. 43

allocating production in unit operations shall be revised if after a hearing the division finds that the revised method is likely to result in a more equitable allocation and protection of correlative rights. The division shall hold a hearing to consider adoption of a revised allocation method upon the application of any affected person, but the application may not be made until three years after the initial order by the division or at less than two-year intervals after that.

(d) A provision for adjustment among the owners of the unit area (not including royalty owners) of their respective investment in wells, tanks, pumps, machinery, materials, equipment, and other things and services of value attributable to the unit operations. The amount to be charged unit operations for each item shall be determined by the owners of the unit area (not including royalty owners), but if the owners of the unit area are unable to agree upon the amount of the charges or to agree upon the correctness of same, the division shall determine them after due notice and hearing, upon the application of any affected party. The net amount charged against the owner of a separately-owned tract shall be considered an expense of unit operation chargeable against that tract. The adjustments provided for in this subsection may be treated separately and handled by agreements separate from the unitization agreement.

(e) A provision providing how the costs of unit operations, Including capital investments, shall be determined and charged to the separately-owned tracts and how these costs shall be paid, including provision providing when, how, and by whom the unit production allocated to an owmer who does not pay the share of the cost of unit operation charged to that owner, or the interest of that owner, may be sold and the proceeds applied to the payment of the costs. The operator of the unit shall have a first and prior lien for costs incurred 
S. B. No. 43

pursuant to the plan of unitization upon each owner's geothermal rights and his share of unitized production to secure the payment of the owner's proportionate part of the cost of developing and operating the unit area. This lien may be established and enforced in the same manner as provided by sections 38-1-8 through 38-1-26. For these purposes any nonconsenting owner shall be deemed to have contracted with the unit operator for his proportionate part of the cost of developing and operating the unit area. A transfer or conversion of any owner's interest or any portion of it, however accomplished, after the effective date of the order creating the unit, shall not relieve the transferred interest of the operator's lien on the interest for the cost and expense of unit operations.

(f) A provision, if necessary, for carrying or otherwise financing any person who elects to be carried or otherwise financed, allowing a reasonable interest charge for this service payable out of that person's share of the production.

(g) A provision for the supervision and conduct of the unit operations, in respect to which each person shall have a vote with a value corresponding to the percentage of the costs of unit operations chargeable against the interest of that person.

(h) Such additional provisions that are found to be appropriate for carrying on the unit operations.

(5) No order of the division providing for unit operations shall become effective unless and until the plan for operations prescribed by the division has been approved.in writing by those persons, who under the division's order, will be required to pay $66 \%$ of the costs of the unit operation, and also by the owners of $66 \%$ of the production or proceeds of same that are free of costs, such as royalties, overriding royalties, and production payments; and the division has made a 
S. B. No. 43

finding that the plan for unit operations has been so approved. If the persons owning the required percentage of interest in the unit area do not approve the plan within six months from the date on which the order is made, the order shall be ineffective and shall be revoked by the division unless for good cause shown the division extends this time.

(6) An order providing for unit operations may be amended by an order of the division in the same manner and subject to the same conditions as an original order for unit operations; but if this amendment affects only the rights and interests of the owners, the approval of the amendment by the owners of royalty, overriding royalty, production payments, and other interests which are free of costs shall not be required. Production allocation may be amended only according to subsection 73-21-7 (4) (c).

(7) A.11 operations, including, but not limited to, the commencement, drilling, or operation of a well upon any portion of the unit area shall be deemed for all purposes the conduct of such operations upon each separately-owned tract in the unit by the several owners of tracts in the unit. The portions of the unit production allocated to a separately-owned tract in a unit area shall, when produced, be deemed for all purposes to have been actually produced from that tract by a well drilled on it. Good faith operations conducted pursuant to an order of the division providing for unit operations shall constitute a complete defense to any suit alleging breach of lease or of contractual obligations covering lands in the unit area to the extent that compliance with these obligations cannot be had because of the order of the division.

(8) The portion of the unit production allocated to any tract, and the proceeds from the sale of this production, shall be the property and income of the several persons to whom, or 
S. B. No. 43

to whose credit, the same are allocated or payable under the order providing for unit operations.

(9) Except to the extent that the parties affected so agree and as provided in subsection 73-21-7 (4) (e), no order providing for unit operations shall be construed to result in a transfer of all or any part of the title of any person to the geothermal resource rights in any tract in the unit area. All property, whether real or personal, that may be acquired in the conduct of unit operations shall be acquired for the account of the owners within the unit area and shall be the property of these owners in the proportion that the expenses of unit operations are charged.

Section 8. Section 73-21-8, Utah Code Annotated 1953, is enacted to read:

73-21-8. (1) Geothermal fluids are deemed to be a special kind of underground water resource, related to and potentially affecting other water resources of the state. The utilization or distribution for their thermal content and subsurface injection or disposal of same shall constitute a beneficial use of the water resources of the state.

(2) (a) Geothermal owners shall, prior to the commencement of, or increase in, production from a well or group of wells to be operated in concert, file an application with the division to appropriate such geothermal fluids as will be extracted from the well or group of wells. Publication of applications shall be made as provided in section 73-3-6, and protests may be filed as provided in section 73-3-7. The division shall approve an application if it finds that the applicant is a geothermal owner and that the proposed extraction of geothermal fluids will not impair existing rights to the waters of the state.

(b) The division may grant the quantity of an application on a provisional basis, to be finalized upon stabilization of 
S. B. No. 43

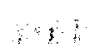

well production. Flow testing of a discovery well shall not require an application to appropriate geothermal fluids.

(3) The date of an application to appropriate geothermal fluids, when approved by the division, shall be the priority date as between the geothermal owner and the owners of rights to water other than geothermal fluids. No priorities shall be created among geothermal owners by the approval of an application to appropriate geothermal fluids.

section 9. Section 73-21-9, Utah Code Annotated 1953, is enacted to read:

73-21-9. Rights to geothermal resources and to geothermal fluids to be extracted in the course of production of geothermal resources acquired under section 73-21-8 shall be based on the principle of correlative rights.

Section 10. Section 73-21-10, Utah Code Annotated 1953, is enacted to read:

73-21-10. (1) Any person adversely affected by any rule, regulation, or order issued under this chapter may within 60 days after the effective date of the rule or regulation or entry of the order bring a civil suit against the division in the district court of salt lake county or in the district court of the county in which the complaining person resides to test the validity of the rule, regulation, or order, or to secure an injunction or to obtain other appropriate relief, including all rights of appeal.

(2) An action or appeal involving any provision of this chapter, or a rule, regulation, or order issued under it shall be determined as expeditiously as feasible. The trial court shall determine the issues on both questions of law and fact and shall affirm or set aside the rule, regulation, or order, or remand the cause to the division for further proceedings. The court is authorized to enjoin permanently the enforcement by the division of this chapter, or any act done or threatened 
S. B. No. 43

under $i t$, if the plaintiff shall show that as to him the act or conduct complained of is unreasonable, unjust, arbitrary, or capricious, or violates any constitutional right of the plaintiff or if the plaintiff shows that the act complained of constitutes or results in waste or does not in a reasonable manner accomplish an end that is the purpose of this chapter.

(3) Any person who, for the purpose of evading this chapter or any rule, regulation, or order of the division issued under it, shall make or cause to be made any false entry in any report, record, account, or memorandum required by this chapter, or by any rule, regulation, or order issued under it, or shali omit or cause to be omitted from the report, record, account, or memorandum, full, true and correct entries as required by this chapter, or by the rule, regulation, or order, or shall remove from this state or destroy, mutilate, alter, or falsify the record, account, or memorandum, is guilty of a class a misdemeanor.

(4) No suit, action, or other proceeding based upon a violation of this chapter or any rule, regulation, or order of the division issued under it shall be commenced or maintained unless same shall have been commenced within two years from the date of the alleged violation.

section 11. If any provision of this act, or the application of any provision to any person or circumstance, is held invalid, the remainder of this act shall not be affected thereby.

Section 12. Section 73-1-20, Utah Code Annotated 1953, as enacted by Chapter 189, Laws of Utah 1973, is repealed. 